E International

\title{
What is Rail Efficiency and How Can it Be Changed?
}

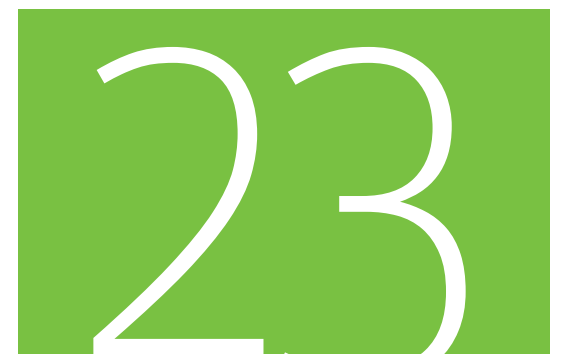

Discussion Paper 2014 • 23

Louis S. Thompson

Thompson Galenson \& Associates, Saratoga, CA, USA

Heiner Bente

Civity Management Consultants, Hamburg, Germany 


\title{
International Transport Forum
}

\section{What is Rail Efficiency and How Can It Be Changed?}

\author{
Discussion Paper 2014-23 \\ Prepared for the Roundtable: \\ Efficiency in Railway Operations and \\ Infrastructure Management \\ 18-19 November 2014, \\ International Energy Agency, Paris, France
}

Louis S. Thompson

Thompson Galenson \& Associates

Saratoga, CA

USA

\section{Heiner Bente}

Civity Management Consultants

Hamburg

Germany

December 2014 


\section{THE INTERNATIONAL TRANSPORT FORUM}

The International Transport Forum at the OECD is an intergovernmental organisation with 54 member countries. It acts as a strategic think-tank, with the objective of helping shape the transport policy agenda on a global level and ensuring that it contributes to economic growth, environmental protection, social inclusion and the preservation of human life and well-being. The International Transport Forum organises an annual summit of Ministers along with leading representatives from industry, civil society and academia.

The International Transport Forum was created under a Declaration issued by the Council of Ministers of the ECMT (European Conference of Ministers of Transport) at its Ministerial Session in May 2006 under the legal authority of the Protocol of the ECMT, signed in Brussels on 17 October 1953, and legal instruments of the OECD.

The Members of the Forum are: Albania, Armenia, Australia, Austria, Azerbaijan, Belarus, Belgium, Bosnia and Herzegovina, Bulgaria, Canada, Chile, People's Republic of China, Croatia, Czech Republic, Denmark, Estonia, Finland, France, Former Yugoslav Republic of Macedonia, Georgia, Germany, Greece, Hungary, Iceland, India, Ireland, Italy, Japan, Korea, Latvia, Liechtenstein, Lithuania, Luxembourg, Malta, Mexico, Republic of Moldova, Montenegro, the Netherlands, New Zealand, Norway, Poland, Portugal, Romania, Russian Federation, Serbia, Slovak Republic, Slovenia, Spain, Sweden, Switzerland, Turkey, Ukraine, United Kingdom and United States.

The International Transport Forum's Research Centre gathers statistics and conducts co-operative research programmes addressing all modes of transport. Its findings are widely disseminated and support policymaking in Member countries as well as contributing to the annual summit.

\section{Discussion Papers}

The International Transport Forum's Discussion Paper Series makes economic research, commissioned or carried out at its Research Centre, available to researchers and practitioners. The aim is to contribute to the understanding of the transport sector and to provide inputs to transport policy design.

ITF Discussion Papers should not be reported as representing the official views of the ITF or of its member countries. The opinions expressed and arguments employed are those of the authors.

Discussion Papers describe preliminary results or research in progress by the author(s) and are published to stimulate discussion on a broad range of issues on which the ITF works. Comments on Discussion Papers are welcomed, and may be sent to: International Transport Forum/OECD, 2 rue André-Pascal, 75775 Paris Cedex 16, France.

For further information on the Discussion Papers and other JTRC activities, please email: itf.contact@oecd.org

The Discussion Papers can be downloaded from:

www.internationaltransportforum.org/jtrc/DiscussionPapers/jtrcpapers.html

The International Transport Forum's website is at: www.internationaltransportforum.org

This document and any map included herein are without prejudice to the status of or sovereignty over any territory, to the delimitation of international frontiers and boundaries and to the name of any territory, city or area. 


\section{Table of Contents}

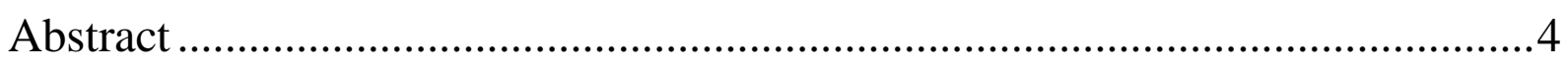

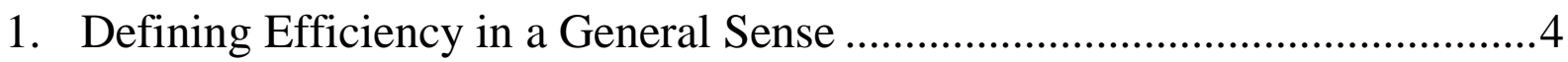

2. Indicators Available From Published Data ....................................................5

3. Initial Rankings Based on Cross-Sectional Comparisons and Initial Discussion of Time-Series Data ............................................................

4. How Can Efficiency Be Changed?.............................................................12

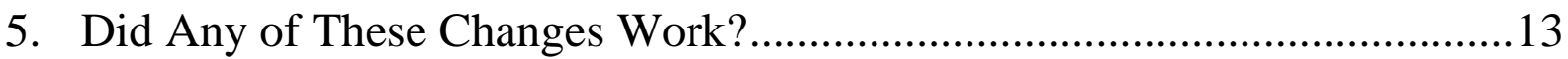

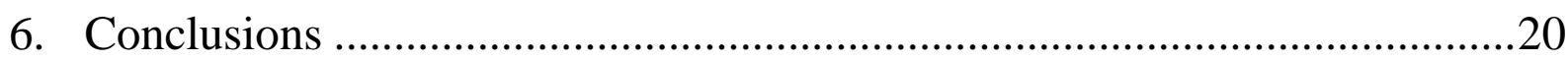

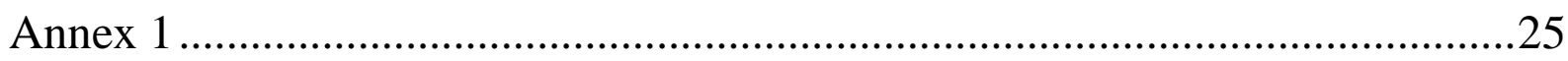

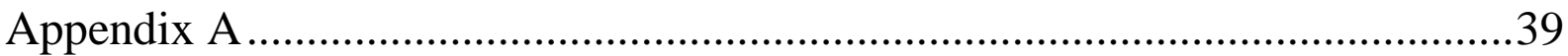

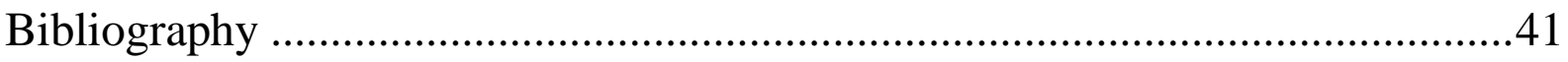




\begin{abstract}
Assessing railway efficiency is complex for a number of reasons. Railways produce a wide range of outputs including passenger service, freight service and, in some cases, separated infrastructure access services. Railways that differ in scale or in the mix of these services inherently differ in their apparent "efficiency." Railway data sets, though probably more detailed than in other modes, are fraught with issues of quality, consistency and cost and asset allocation. Assessing "efficiency" necessarily requires both cross-sectional indices to put each railway into proper context and time series data to show changes in performance over time in response to changes in the railway's economic and policy environment.

This paper assembles a wide database of railway data relating to operating scale and various indices of performance over the period of 1970 to 2011 . We show, as expected, that railways differ widely in scale and mix of services, which may partly explain differences in ranking by performance indices. We show also that railway performance has changed greatly over time and that, in some cases, changes in performance can at least partly be attributed to reforms in structure, ownership and management incentives.
\end{abstract}

\title{
1. Defining Efficiency in a General Sense
}

In the abstract, what we mean by "efficiency" or productivity (we will use these terms essentially interchangeably) is maximizing the outputs from a set of inputs or maximizing the ratio of outputs/outputs. Efficiency is not a standalone concept, however; efficiency is always dependent on a comparative context. We need to know how a given performance compares with others.

Defining and measuring efficiency or productivity in the railway context is a complex problem because:

- Size and scale matter. Large railways and highly dense railways have a potential advantage in efficiency because some parts of railway operations are subject to returns to scale, at least over the range below the very largest systems.

- The mix of services matters. Most measures of productivity appear to show that passenger service is less "productive" than freight. That is, a passenger-km tends to require more resources to produce than a tonne-km: after all, many countries operate 10000 tonnes (or greater) unit freight trains while passenger trains carrying more than 1000 passengers are rare (see Mumbai commuter trains, however). Moreover, freight is generally considered to be "commercial" and market-driven and managers have an opportunity to set reasonably clear management objectives: passenger 
services are typically justified by social as well as financial performance, leading to political involvement and mixed, even contradictory management objectives.

- Evaluating railway efficiency therefore requires a number of different types of indices relating to scale, asset productivity (including labor), financial indices (revenue-cost) and economic measures that include social costs and social benefits. No single index can ever be dispositive. Instead, we will need to look at a collection of indices to see which railways tend to fall at the bottom of the pack and which tend to rise to the top.

- The complexity of measures makes it important to have two types of indices, cross-section (comparing railway systems at a single point in time) and time series (change over time). There can well be reasons for a lower ranking on various cross-sectional indices, especially when some railways are forced by government to provide large quantities of politically driven regional or commuter services (whether or not compensated by PSO payments), or where regulation suppresses tariffs and harms financial performance. Even where a plausible case can be made for lower comparative performance, though, adverse changes over time are harder to explain.

\section{Indicators Available From Published Data ${ }^{1}$}

Indicators of efficiency or productivity can be developed at many different levels. The objective of this paper is to identify indicators that can be developed from publicly available data. We recognize that some measures would require much more detailed information, such as a comparison of the costs of DB versus Network Rail in maintaining a Km of electrified line with comparable traffic levels. Unfortunately, information at these detailed levels is either not collected or not reported publicly. ${ }^{2}$ Appendix A contains a detailed discussion of the sources of data used in this paper. The dataset developed covers the period 1970 to 2011 (in some cases later) for time series purposes and furnishes a complete cross-sectional set for 2011. The data set includes all EU railways (separated between the EU15 and EU10) along with Switzerland and Norway. In addition, for comparison we include China, the U.S. (Class I freight railways and Amtrak), Canada (freight railways and VIA), Japan and, in some cases, Indian Railways (IR).

- The basic indices of size and scale are (see Table 1 for a key to the countries, railways and groupings employed in this analysis and Table 2 for summary data):

\footnotetext{
${ }^{1}$ Unless otherwise specifically indicated, all data are expressed in metric terms - Tonnes and Kilometres. Unless otherwise specified, Tonnes means net Tonnes.

2 The International Union of Railways (UIC) sponsored a series of studies of relative efficiency of track maintenance among a number of railways. Unfortunately, the identity of railways in the dataset was concealed, depriving outside analysts of the ability to put the relative performance of each railway into context. This also deprived governments of the ability to assess the performance of their own railways and to decide whether the public was getting value for money. Beck et al., 2012 suffers from the same "confidentiality" restrictions. An explicit objective of this study is to rely only on data sets that are publicly available.
} 
- Passenger data: Passengers carried ${ }^{3}$, Passenger-Kms, Gross Tonne-Kms for passenger trains, Passenger Train-Kms, Coaches, DMUs and EMUs;

- Freight data: Tonnes carried, Tonne-Kms moved, Gross Tonne-Kms of freight moved, Freight Train-Kms and Freight Wagons ${ }^{4}$;

○ Common or joint assets: Locomotives, Labor, Kms of Line;

- Financial and economic performance: Total Operating Cost, Total Operating Revenue, Passenger Revenue, Freight Revenue.

- Ratios of efficiency and productivity developed from the measures above:

- Average trip length for passengers (Passenger-Kms/Passengers), and average length of haul for freight (Tonne-Kms/Tonnes). Table 3.

○ Passenger share of Traffic Units (TU): Passenger-Kms/(Passenger-Kms + Tonne-Kms). Table 4.

○ Passenger share of Gross Tonne-Kms: (Passenger GT-Km/(Passenger GT-Kms+Freight GT-Kms). Table 4.

- Passenger share of Train-Kms: Passenger Train-Kms/(Pass. Train-Kms+Frt Train-Kms). Table 4.

- Traffic density: TU/Line Kms, Gross Tonne-Kms/Line Kms and Train-Kms/Line Kms. Table 5.

○ Coach Productivity: Passenger-Kms/(Coaches+ DMUs+EMUs). Table 6.

○ Wagon Productivity: Tonne-Kms/Wagon. Table 6

○ Locomotive Usage: TU/(Locomotives + MU factor) ${ }^{5}$ Table 6 .

○ Labor productivity: TU/Employees, Gross Tonne-Kms/Employees and TrainKms/Employees. Table 7.

- Operating Ratio: Operating Cost/Operating Revenue. This is a commonly used measure of financial performance and an indication of the railway's ability to cover its financial obligations. ${ }^{6}$ Table 8.

\footnotetext{
${ }^{3}$ We highlight the fact that there can well be double counting on passengers carried and freight tonnes carried since the same passenger (or tonne) can cross a railway border and be counted each time. Passenger-km and Tonne-km are not subject to double counting. Given that the average trip length of most EU railways is quite short, this issue may not be as significant for passengers as for freight.

${ }^{4}$ Numbers of freight wagons are also affected in countries where there are significant numbers of lessor or shipper owned wagons that do not appear as railway-owned assets. For example, only one-third of U.S. freight wagons are owned by railways.

${ }^{5}$ Measuring locomotive productivity is complicated by the presence of DMUs and EMUs that have their own tractive effort. We attempt to correct for this by calculating effective locomotives by dividing DMU or EMU numbers by a factor that represents the average length of a DMU or EMU train. We acknowledge that this is at best an approximation. Of course, on freight-only railways or railways without MUs it is not a problem.
} 
- Average Revenue per Passenger-Km and per Tonne-Km. These are measures of the railway's average tariffs and give an indication of the railways cost levels combined with government subsidy policy. These measures show performance from the customer's point of view - how much do I have to pay? In addition, they give a good indication of the railway's charges compared with competing modes. These measures are presented in constant 2011 Purchasing Power Parity Adjusted (PPP) international dollars. This involves several revenue conversions: 1) into constant local currency (which requires conversion from local to Euros in those countries joining the Euro); 2) into USD at 2011 conversion rates; and, 3 ) into PPP \$. Although this chain of conversions clearly introduces potential errors at every stage, we believe it is interesting because it furnishes a general comparison of amounts that users actually pay in various countries and especially because it shows the impact (if any) on railway users of the various reform programs. Table 9.

- Market shares for passenger and freight from OECD data of freight and passenger traffic for all modes since 1970. This is the best available measure of how the railway has performed in competition with highway, water and air traffic and is a measure of the impact of reforms on the railway's competitive position. Table 10.

\section{Initial Rankings Based on Cross-Sectional Comparisons and Initial Discussion of Time-Series Data}

The data available are far too extensive for a detailed review of every railway. Instead, we can briefly summarize the highlights of the basic performance indices illustrated in Tables 1-10.

- Table 1 provides a listing of all railway entities on which at least partial data have been collected and show how the Tables distinguish among EU 15, EU 10 (and Croatia), Norway and Switzerland, and all other railways. It also provides the railway abbreviations that are used throughout this paper.

- Table 2 shows Employees (Labor Force), Line Kms, Passenger-Kms and Tonne-Kms. There are some railways, notably China, U.S. Class I freight, Indian Railways and Japanese railways that are immense industrial undertakings by any measure. SNCF, DB AG, PKP, FS and the UK rail system appear at the upper end of the ranges as well. By comparison, many of the EU's smaller railways are one-one thousandth (or less) of the size of the largest railways. Although there have been studies arguing that returns to scale in railways taper off beyond a certain size (and some of the largest appear to be at or beyond this point), there is little question that many of the smaller railways will inherently be on the less efficient end of the scale. This has to be considered when assessing their performance.

\footnotetext{
${ }^{6}$ The Operating Ratio includes depreciation and amortization but excludes payments to acquire and compensate sources of capital.
} 
- Table 3 shows the average trip distance for passengers and the average length of haul for freight. Railways with a longer average trip are in a different market segment than those with mostly short trips. CR, Amtrak and VIA, for example, operate numerous long-haul trains with sleepers and diners and, for Amtrak and VIA, are partly in the cruise business and partly compete with air travel. A critical characteristic of most of the EU railways is their very short average length of passenger trips, which means that they operate mostly short intercity trips or commuter services. At these trip lengths, auto and bus are the main alternatives. Somewhat the same phenomenon shows up even more strongly in freight where U.S. Class I, CR, Canada and IR operate with lengths of haul long enough to fully capture the economic advantages of long haul, heavy loading freight traffic. By comparison, most of the EU railways are constrained to operate at lengths of haul where trucking becomes more competitive. We highlight here that there is a real possibility that the EU lengths of rail freight haulage (and passengers to a lesser extent) may be distorted to appear lower than actual by double counting of the tonnes handled when traffic crosses national borders. $^{7}$ This also highlights the need for better Origin to Destination rail traffic data in addition to that reported by the individual railways. ${ }^{8}$

- Table 4 shows the role of passenger traffic in the total traffic of each railway, first as a percent of Traffic Units (the sum of Passenger-Kms plus Tonne-Kms), then as a percent of Gross Tonne$\mathrm{Kms}$ and then as a percent of Train-Kms - three different aspects of rail service. Traffic Units give a basic picture of the relative markets the railway serves, Gross Tonne-Kms gives at least an indication of the relative maintenance burden imposed by each type of service, and Train-Kms gives a rough picture of the relative usage of line capacity, which is the basic limitation on the ability of the railway to provide service. By these measures, the EU 15 railways tend to be passenger dominant, the EU 10 railways less so, Japan is highly passenger dominant, and the U.S., Canada and CR are freight dominant. It is also significant to note that the passenger share of Train-Km tends to be higher than TU or Gross Tonne-Km, indicating that measures of efficiency of system use should look at all three measures in order to account for services, wear and tear in the system and usage of capacity.

- Table 5 then looks at measures of line traffic density according to TU/Km, Gross Tonne-Kms/Km and Train-Kms $/ \mathrm{Km}$. It is interesting that CR and U.S. Class I tend to rank higher by the first two measures whereas the EU railways rank higher by the third. We could say that the U.S. Class I railways, for example, are more efficient at using their tracks to move volumes of freight, but the EU railways are more efficient at moving trains carrying passengers. From another viewpoint, we could argue that the focus in the EU on using line capacity to emphasize Train-Kms may well limit the ability of the systems to move freight that requires fewer Train-Kms but can interfere with passenger trains because of the speed difference between freight and passenger trains.

- Table 6 provides a series of measures of the productivity of rolling stock. The measure for Coaches is Passenger-Km/coaches including MU Coaches. Wagon productivity is shown as Tonne-Km/Wagon fleet. Locomotive productivity is TU/Locomotives plus an adjusted number of MUs to reflect the fact that MUs provide tractive effort. The adjustment factor used divides the number of MUs by 6: we recognize this as at best an approximation. In fact, while the Coach measure pertains only to passenger service and the wagon measure pertains only to freight, and are

\footnotetext{
${ }^{7}$ This could be corrected if railways distinguished between tonnes originated as opposed to total tonnes handled and tonnes originated off line and terminated off line.

${ }^{8}$ A similar problem appeared in the US Carload Waybill Statistics in the early years of waybill reporting because each railway in a multiple railway shipment could report the same tonnage. This has since been corrected. See McCullough 2012 for a detailed discussion of the issue.
} 
thus reasonably separable, the locomotive measure necessarily includes both services (except for railways that provide only freight or only passenger service) since locomotives are often used interchangeably. Once again, in terms of locomotive usage intensity, the major freight railways tend to predominate. IR, CR, SBB and Japan stand well above the rest in Coach productivity.

- Table 7 shows output per employee as measured by TU/Employee, Gross Tonne-Kms/Employee and Train-Kms/Employee. The U.S. Class I and Canadian freight railways stand far above the pack in TU and Gross Tonne-Kms per employee, but are in the middle of the pack for Train$\mathrm{Kms} /$ Employee. This reflects the same difference in focus where, in order to reduce labor costs, the U.S. and Canada run fewer, but long and heavy trains whereas the EU systems run higher frequencies of shorter trains primarily because passengers place a higher value on service frequency than do freight shippers.

- Table 8 shows the Operating Ratio, which is the ratio of total Operating Costs (excluding costs of debt and equity) to total Operating Revenues and is a basic measure of financial performance. Railways running an Operating Ratio above approximately $85 \%$ are much less likely to cover their total cost and will require increasing outside support as the ratio becomes higher - they are financially "inefficient" (though they may be economically efficient if they are rendering a social service at low cost and with adequate compensation). By definition, an Operating Ratio above $100 \%$ means that the railway cannot survive without outside assistance. The critical observation is how few railways even approach being self-sufficient financially. This may be well within the fiscal boundaries established by governments, but it does ensure that railways are enmeshed in the annual politics of public finance: note, for example, that the U.S. Class I railways are profitable (Operating Ratio of 73.2\%) whereas Amtrak (Operating Ratio of $150.2 \%$ ) is dependent on public finance. It is also interesting to see that the Operating Ratios of RHK (900\%) and BV/Trafikverket (250\%) reflect the stated policies of the Finnish and Swedish governments to collect only marginal costs of infrastructure provision from users. By comparison, an estimate of the Operating Ratio for DB Netz is $86.9 \%$, reflecting the stated goal of the government to collect the full cost of operations from users. The reported Operating Ratio of RFF (78.7\%) is also surprisingly low, and perhaps explains the complaints of SNCF that access charges were too high. It will be interesting to see what happens to this ratio when RFF is re-merged with the SNCF parent company. The Annual Reports of Network Rail stated an Operating Ratio of 64.5\%, which would again reflect a policy of collecting full cost from users. We emphasize, though, that these measures are particularly sensitive to accounting issues and to the transparent accounting (or lack thereof) for public support.

- Table 9 shows the most important index of efficiency from the point of the view of the customer prices charged. In Table 9, we have converted average revenues per Passenger-Km and per Tonne-Km into 2011 USD at Purchasing Power Parity (PPP). Because this involves conversion of currencies first into constant terms, then into a common currency, and then into PPP terms, it is clearly subject to a range of error. With this acknowledged, it is interesting to see that the average passenger tariffs of many EU railways are well into the range of low-cost airlines as well as costs of auto operation, which does not bode well for competition except in congested urban environments. Similarly, many of the EU railways charge average freight tariffs that are roughly comparable to trucking costs and thus subject to intense competition. Extremely low passenger tariffs on some railways (IR) reflect a desire to use freight income to pay for passenger losses caused by politically suppressed passenger fares.

- Table 10 shows the market share (percent of Passenger-Km) of rail transport in the passenger sector in competition with autos and buses. It also shows the rail market share (percent of Tonne$\mathrm{Km}$ ) vis-a-vis the entire surface transport market (trucks, water and pipeline) and then rail market 
share vis-a-vis trucks only. In a direct sense, this is not so much a measure of rail efficiency as it is a measure of the result of rail efficiency (or lack thereof) in the overall market. An inefficient railway will perform poorly, an efficient railway has a chance to perform well. We argue that the competition of rail versus trucks is probably the best measure of rail's performance in the transport markets. As this Table shows, rail plays a very different role in some countries than in others.

For example, rail plays practically no role in U.S. and Canadian intercity passenger transport but is predominant in Japan.

Because the amount of information to be presented would be too large, we selected a few indicators and a few countries to display a sample of the time-series information that is available. We show only the years 1970, 1975, 1980, 1985, 1990, 1995, 2000, and 2005-2011 (interim years are available in the underlying database). We select France (SNCF), Germany (DB through 1995 and DB AG for 19952011), and the UK (old BR before 1995, ATOC, UK freight and Network Rail afterward): these railways together account for about 60 percent of all EU 15 railway traffic. We show the Czech Republic (CD) and Poland (PKP) as these represent about 60 percent of traffic in the EU 10 and because the data available are not complicated by changes in corporate structure. We also show the U.S., Japan and Switzerland (SBB) to represent railway activity outside the EU We use 1980 and 1995 as base years: 1980 is a point in the development of the EU when railways began to be affected by the overall economic changes, and is also the year before deregulation in the US; 1995 is close to the beginning of the Commission's attempts to restructure the EU railways.

- Table 11 gives an overall picture of how railway traffic has developed over time. Notable from this Table is the fact that rail passenger traffic grew faster in the UK than in SNCF and DB, especially after 1995 . UK freight traffic also grew faster. Rail traffic has been shrinking in the EU 10 and had, at best, stabilized by 2011. Swiss traffic trends essentially mirrored those of the EU 15, while Japanese passenger and freight traffic were stagnant or slowly shrinking. U.S. passenger traffic grew slowly while freight traffic grew strongly, especially from the base in 1980.

- Table 12 shows the evolution in Operating Ratios and Labor Productivity (using TU/Employee). There is a mild improvement in Operating Ratio in most countries, with a marked improvement in U.S. Class I freight railways and in Japan. With this said, it is interesting to note the difference between the U.S. Class I railways (73\%) and Amtrak (150\%). Labor productivity improved in all countries, with the greatest growth rate in the U.S. Class I freight railroads, UK and Japan.

- Table 13 shows the side of the railways that the consumer sees - average tariffs. There was an apparent trend upward in average passenger tariffs in every country from 1980 and in all but one (Japan) from 1995. Average freight rates were stable or trending downward in most countries; but, only in the U.S. Class I railroads do they appear to be well below competitive trucking rates. We stress again here that the calculation of average rail tariffs is inherently an approximation because of all of the conversions involved. We do believe that they are usefully indicative both as to levels and changes over time, but they do need to be viewed with some caution.

- Table 14 shows the evolution in market shares in passenger and freight markets. The rail passenger share of the EU 15 railways ( 7\%) has changed little since 1980 and 1995 whereas the rail passenger share in the EU 10 countries has rapidly fallen to EU 15 levels. Rail passenger traffic has an insignificant share in the U.S. and that has not changed. ${ }^{9}$ Japanese rail passenger shares have been stable at a level much higher than the EU, while Swiss rail passenger shares have

\footnotetext{
${ }^{9}$ This is to some extent the result of exclusion of the traffic of U.S. commuter railways (which is included in the EU, Swiss and Japanese results). U.S. commuter railways carry slightly more Passenger-Km than Amtrak, so the U.S. share would double, but still remain below $1 \%$ if auto traffic is included.
} 
grown slightly and are about twice the EU levels. The picture for rail freight is quite different: EU 15 rail freight shares have fallen since 1980 but have remained stable since 1995. EU 10 rail freight shares have fallen dramatically since 1980 and 1995, though they may now be stabilizing at a level slightly above that of the EU 15. Interestingly, the Swiss rail freight market share is much higher than in the EU, though it has fallen somewhat since 1980 and 1995. The U.S. rail freight market share has stabilized since 1980, though it was falling rapidly before then (it was $78 \%$ in 1950 and $67 \%$ in 1960).

At this point we can answer the first issue posed in this paper. Yes, there are measures of efficiency or productivity that can be developed from publicly available data. The measures we have developed do give an overall picture of the performance of the selected railways both in cross-section (2011) and over time (1970 to 2011). It is possible from these measures to identify the more efficient railways: China in both freight and passengers, U.S. and Canadian Class I railways in freight, and Japan for passenger service. Within Europe, SBB seems to measure up quite well while the EU 15 and EU 10 railways present a mixed picture. It would also be possible to use the data developed to assess the efficiency of a specified railway and track its progression over time if that were desired.

With this said, these measures could be greatly improved in the EU by having a regulatory body that could specify the data to be reported by every railway, verify its accuracy and require its production annually. ${ }^{10}$ It is possible that many of the gaps identified in the database could be filled by reference to Annual Reports or other national documents, but there is no single point of reference for complete and consistent reports.

In fact, the EU data gaps and consistency problems underline an important challenge in measuring and comparing railway efficiency - most railways either do not see the need for detailed information for internal management purposes or do not think it is in their interest to release such information to permit public comparisons to be made. For example, as mentioned earlier the data in "Railway Efficiency," (Beck 2012) conceals the identity of the railways in the comparison, significantly vitiating the use of the results. This has long been the practice of the UIC in making comparisons of relative performance of its members. Under what circumstances should public entities, supported by public funding, be allowed to conceal information that would facilitate public analysis and evaluation of their performance? This will be a point to consider in the analysis of the interaction among ownership, structure and performance measurement discussed below. It is also a critical point in assessing whether the Commission's railway objectives - transparent accounting for infrastructure to ensure fair access and financial stability of the infrastructure agency accompanied by separated accounts for passenger and rail services - can ever be met.

We argue that the information that the Commission would need to ensure implementation of its Directives with respect to financial transparency of infrastructure, passenger and freight operations simply does not yet exist, and should be added to the task of a designated authority. In addition, one important piece of information - where do passengers and freight shipments actually originate and terminate - is not yet available in the EU and awaits collection of passenger ticket and waybill information. The same issues were described in more detail in "Railway Accounts for Effective Regulation," (Thompson 2007). ${ }^{11}$ The data collected and reported by the U.S. STB, including

\footnotetext{
${ }^{10}$ For railways, this requirement might also be met by encouraging all railway service providers, including infrastructure entities, to complete the existing data requirements of the UIC.

11 See also "Workshop Report - Measuring Investment in Transport Infrastructure," ITF, Paris, France, February 9 and 10, 2012, where exactly the same data issues arise.
} 
"Analysis of Class I Railroads" and "Public Use Carload Waybill Statistics" would be a useful model for EU agencies to consider.

\section{How Can Efficiency Be Changed?}

It is all very well and good to define and measure efficiency (however approximately), but the effort expended in defining, collecting and reporting data will have no payoff if there is nothing that can be done to change the railways' performance. ${ }^{12}$ Fortunately, if railways are willing, and the political will exists, efficiency can be changed.

One way to change efficiency, much favored by traditional, engineering-dominated railway managements, is increased investment (increasing capital intensity). One of the arguments in favor of added investment - making up for deferred maintenance - can well have some justification, although it sometimes simply reflects neglect of a facility that lost its economic role long ago and should be taken out of service. Where legitimate deferred maintenance needs exist, good management (and good public policy) will deal with it. Another argument - replacing old with new without regard to payoff tends to appear when the railway does not face any commercial objectives. In either case, this paper does not look at increased investment alone, although we acknowledge its role in improving efficiency when a good financial or economic case can be made, especially when the success of a new structure depends on a fresh start from years of past investment neglect.

We instead look at various structural or organizational innovations that aimed at changing the underlying objectives or incentives faced by railway management and use the time series data in outlining those changes that seemed to have "worked" and those that have not been as successful.

In general terms, we can identify changes in structure, ownership and incentives, though these can be combined and can work together:

- Structural change means movement along the spectrum that begins with monolithic form (all assets owned by the railway and all services provided by the railway). The Ministry of Railways in China has long been an example of a monolith. China recently separated China Railways (CR) from a newly created Ministry of Railways, so Indian Railways (IR) is the only remaining major railway that is still fully monolithic. There are railway structures where the dominant operator is in control of infrastructure while other operators are tenants on the infrastructure and pay for access (either marginal costs or a negotiated fee). This can include either competing operations in

\footnotetext{
${ }^{12}$ Indeed, the experience of the authors suggests that railway management often resists collecting information, and especially reporting it, on the grounds that they can't do anything with the results anyway. Of course, it could also be because they are concerned that better information might support efforts to change the rules of the game they face (or in fact change them). As a rule of thumb, public ownership and management under political control seem to be antithetical to collection of transparent information, even where the information is for public use. To be fair, private corporations also try to restrict public reporting but, as the STB example demonstrates (ORR in the U.K. is a demonstration of passenger information) these objections can be overcome. Moreover, private corporations are not usually spending public money and, when they are, they are required to report in greater detail.
} 
the same market (freight trackage rights on a freight operator's lines, which covers $27 \%$ of U.S. freight lines) or non-competing operators (passenger) on freight lines (Amtrak and VIA) or, indeed, freight operators on passenger lines (JR Freight). The U.S, Canada and Japan are examples where the dominant operator controls the infrastructure and tenants pay for access. The complete form of structural change is full vertical separation, with an infrastructure provider offering neutral access to all operators in accord with published access charges. The EU Commission's Directives have been aimed at creating vertical separation of infrastructure but the process has been fragmented, inconsistent across member countries and, in many cases, remain incomplete.

- Ownership change means movement along the range from fully public to fully private. U.S. and Canadian freight railways are now fully private, though the Canadian National $(\mathrm{CN})$ was only privatized in 1995 and Conrail was privatized in 1987. Amtrak is a publicly owned corporation. The old Japanese National Railway was broken up (structural change) and the three largest passenger operators privatized in 1987. Most EU railways remain fully public, but the private sector is increasingly being allowed to provide some operating services, both in the passenger and freight markets. The UK was at one time an extreme case of virtually full privatization, but that has evolved back into a public/private balance.

- Changes in incentives ("rules of the game") include situations in which the management of the railway is given more freedom to operate commercially and is given objectives that include at least some degree of risk for cost control or net revenue maximization or both. Management contracting is a starting point, but the process can extend through gross cost or even net cost franchising. ${ }^{13}$ In the U.S. context, deregulation completely changed the ability of freight railways to work directly with shippers to set rates and services that met shipper needs without interference from the regulator.

\section{Did Any of These Changes Work?}

The reform process in the US actually had three parts: formation of Amtrak in 1972 order to free the private freight railroads of the burden of passenger deficits (and, in the minds of some, to free passenger service from the indifference of freight company management); combining the bankrupt freight railroads in the mid-west and northeast part of the country into one entity, refinancing and rebuilding it, and subsequently re-privatizing it in 1987; and deregulation in 1980 (the Staggers Act). As Tables 11 and 12, and Figure 1 show, these reforms were highly successful in stabilizing market share, lowering rates, increasing traffic and improving essentially all indices of efficiency. ${ }^{14}$ The comparison with changes in Amtrak is interesting. Amtrak rates went up (Table 13), service grew slowly (Table 11), and productivity was stagnant (Table 12). Operating Ratios improved for freight and were stagnant (and high for Amtrak). With this said, the essential purpose of Amtrak - to save the freight railways that were staggering under the burden of passenger deficits-was achieved.

\footnotetext{
${ }^{13}$ See ECMT 2007 for a discussion of gross cost and net cost franchising.

${ }^{14}$ See McCullough 2012 for a detailed discussion of the impact of the Staggers Act on U.S. rail freight tariffs and on the profitability of the Class I Railroads. Basically, rates went down and profits went up because productivity increased even more rapidly, especially as a result of contract tariffs.
} 
Figure 1. US Class I Railroads Operating Ratio (\%) and All Commodity Average Revenue/ Ton-Mile (U.S. cents/ton-mile

Avg. Revenue

Operating Ratio (\%)

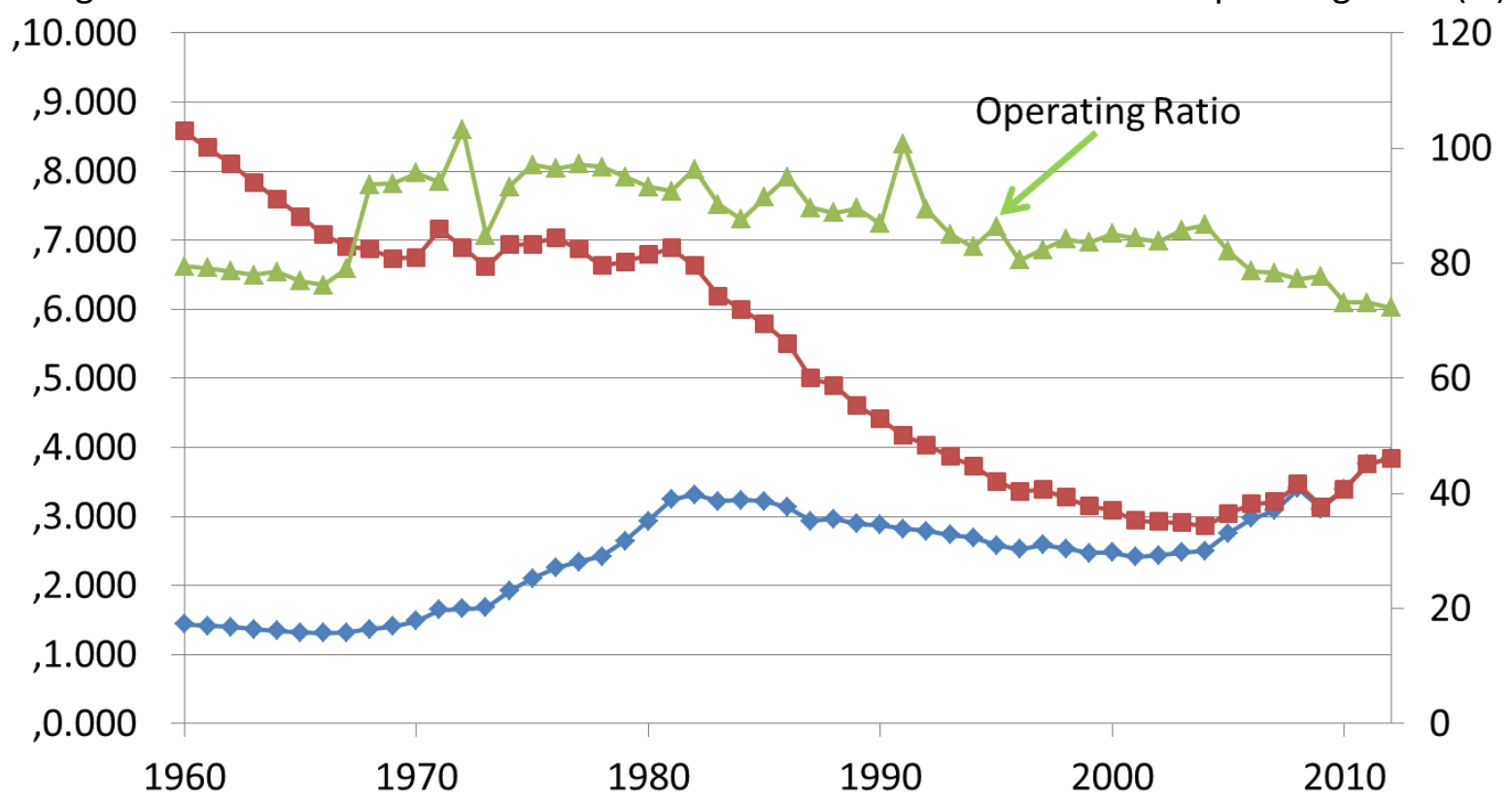

Source: Analysis of Class I Railroads and U.S. Bureau of Economic Analysis (GDP Deflator).

In Canada, privatization of $\mathrm{CN}$ produced a change in relative productivity of $\mathrm{CN}$ with $\mathrm{CP}$ (always private), though the shift was not dramatic. In sum, though, Canadian rail freight rates declined steadily both before and after $\mathrm{CN}$ privatization while labor productivity improved rapidly. Operating Ratios also improved after 1995. Comparing Figure 2 with Figure 1, it is also apparent that the Canadian experience was at least partly driven by deregulation of the U.S. freight railways, with which the Canadian railways both compete and cooperate. ${ }^{15}$ VIA offers the same comparison with the Canadian freight railways as Amtrak does with the Class I U.S. freight railroads: VIA's labor productivity is low (Table 7) and is little changed since establishment in 1980. VIA's Operating Ratio (185.5 - see Table 8) is high although its average tariffs are well below Amtrak and are about at the EU average, but for a very different traffic mix (see Table 3, where VIA has the third longest average length of trip, reflecting the importance of long-haul trains).

15 A recent OECD report (ITF 2014) showed that changes in the structure and ownership of the Mexican railways had a similar effect. 
Figure 2. Canadian Freight Railways

(Tariff index and Labor Productivity Index 1995=100)

Tariff and Labor Index

Operating Ratio

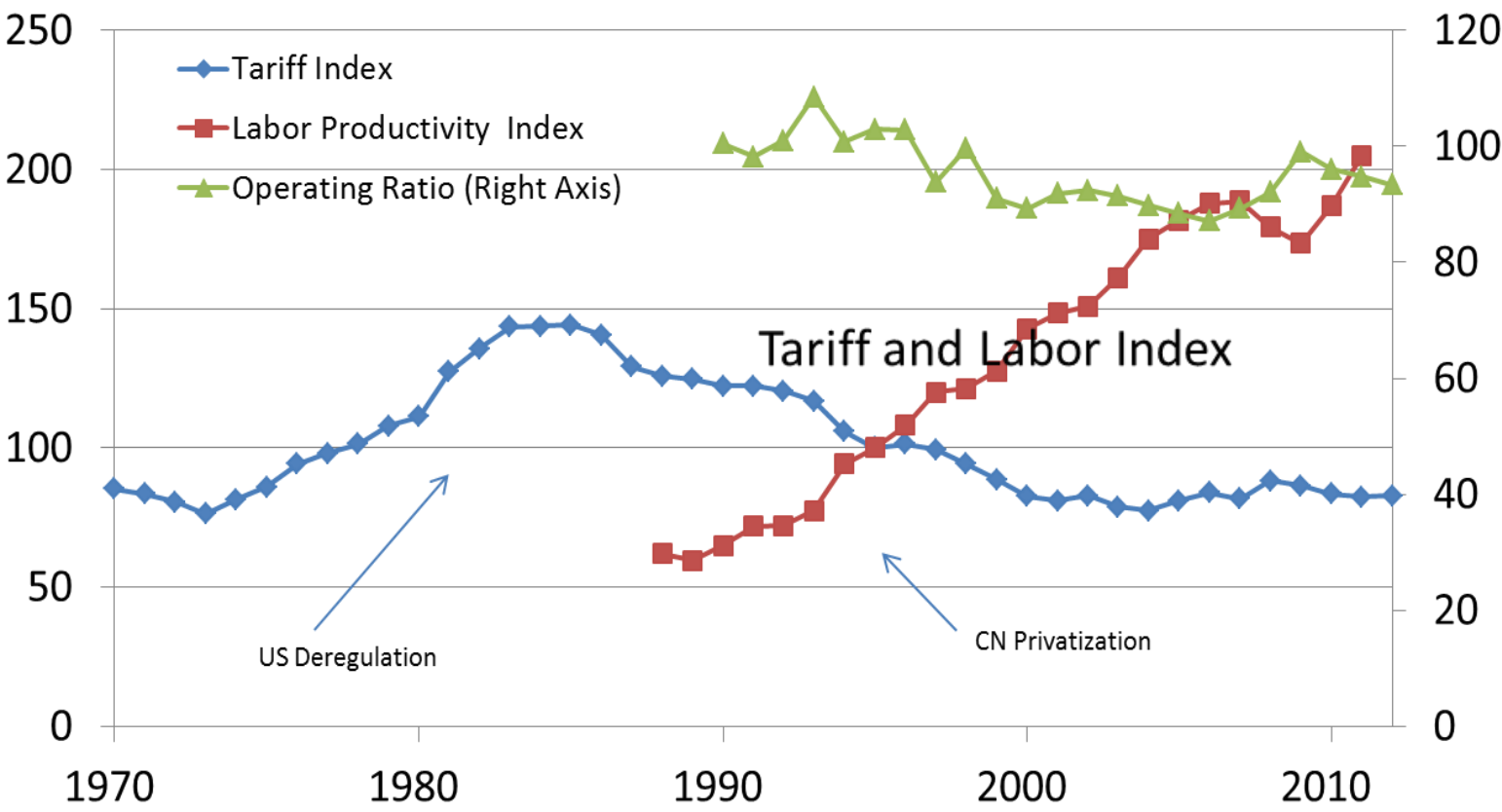

Source: Railway Association of Canada.

In brief, the Japanese reforms involved breaking up the old monolithic Japanese National Railways (JNR) into 6 new passenger companies and a freight company that operates much like a "freight Amtrak" - it pays access charges and uses the narrow gauge lines of the passenger companies (the high-speed lines - Shinkansen - are standard gauge and are not used for freight). The three large passenger companies (JR East, JR West and JR Central) were subsequently privatized by sale of their stock. An explicit goal of the reform was to break the control of the unions over the politically oriented management. As Figure 3 shows, the reforms were highly successful in improving labor productivity and the Operating Ratio for the system. ${ }^{16}$ This was accomplished while tariffs were held stable (Table 13) and total traffic actually remained almost the same over the last 20 years.

Performance of JR Freight is harder to pinpoint. What is clear is that traffic has declined while tariffs have been held stable, roughly at EU levels. In perspective though, JR Freight has faced a problem similar to that of Amtrak: as the traffic of the dominant operator has grown there is less room for the tenant. This has caused Amtrak's on-time performance to plummet and has restricted JR Freight's ability to handle its traffic. It is probably a risk inherent to dominant/tenant schemes (or, arguably, where some operators have closer linkage to infrastructure management than other operators).

\footnotetext{
${ }^{16}$ The Operating Ratios shown are actually for the entire system, and are lowered by the performance of the three smaller railways and the freight company (JR Freight). The Operating Ratio for the three larger companies by themselves would be more favorable.
} 
Figure 3. Changes at JNR at Privatization

[Operating Ratio (\%) and Labor Productivity`]

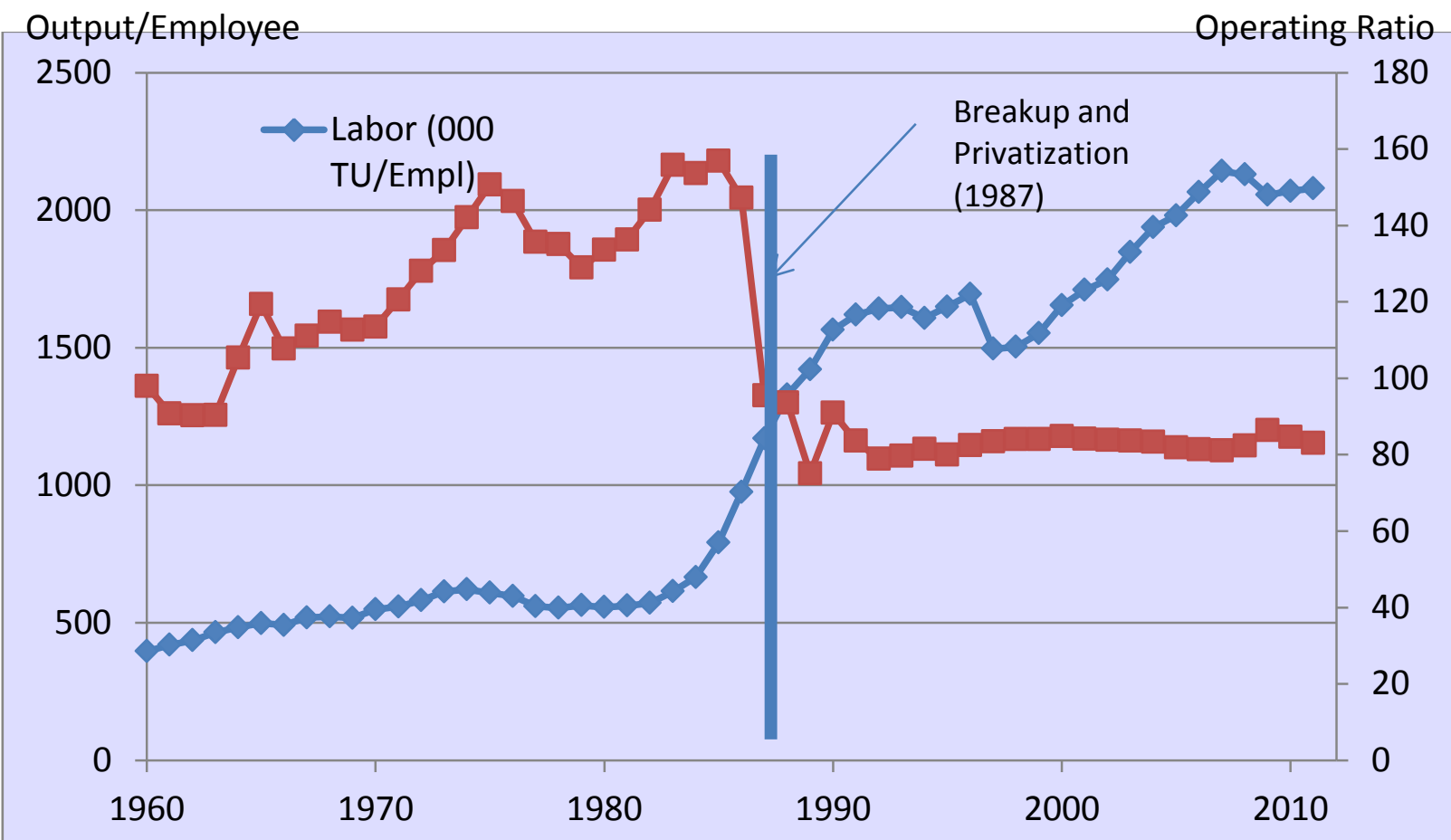

Source: Author's analysis and UIC Railway Time Series, 1970-2000.

Experience in the EU is much more complex to assess. In overall terms the Rail Liberalization studies by Kirchner ${ }^{17}$ suggest that the Commission's structural reforms have gradually been implemented, though the degree differs among members as Table 15 shows. Although the indices are arguable on a number of grounds and are, in any case, only partly objective, Kirchner argued that the market is now more liberal and that the degree of competition has increased.

Table 15 does indicate that the Liberalization Index as computed by Kirchner had improved over the time period (2002, 2004, 2007 and 2011) studies. This appears to have been much more applicable to freight service than passengers, probably because the interaction between public support and passenger service is stronger than in freight. Governments find it hard to allow competition for their supported services, though this has changed in some countries.

It is also significant that Kirchner divided his index into three parts: LEX (legal change); ACCESS (whether the infrastructure agency actually allowed access to take place in accord with the new laws); and COM (a measure of the actual degree of competition that had emerged. Looking at the COM index on Table 15, even by 2011 there was only one country (UK) that had an "advanced" COM index, and only four (Germany, Netherlands, Denmark and Estonia) that were considered "on schedule." It is also interesting that DB AG owns the major freight carrier in Germany, NL and DK (and in the UK), so the apparent degree of freight competition in these countries may be less than

\footnotetext{
${ }^{17}$ Kirchner 2011, but also 2002, 2004 and 2007.
} 
indicated. Estonia essentially exchanges traffic only with Russia (Its Baltic connections are either "delayed" of "pending departure"), so competition would be of limited value.

The relatively slow development of intra-rail competition combined with the slower pace of liberalization in the passenger sector should alert us to have lower expectations for the impacts of the EU reforms, especially in countries slower to adopt the reforms. This effect can be multiplied by the fact that a country might well be aggressive in its reforms only to see the impact muted by slow change in countries to which it connects.

This overall picture of a slow pace of reform in the EU railways developed by Kirchner is supported by the results in Tables 11 and 14. The EU 15 railways do not demonstrate a particularly dynamic performance either measured by freight or passenger traffic growth or by market share. We acknowledge that the outcome could have (we argue would have) been worse without reform, but it is not possible to argue that the reforms have had (to date, at least) anything like the positive impact of the reforms in the U.S., Canada and Japan. It is also possible to argue (as the Kirchner indices suggest) that the restructuring reforms have not actually been implemented yet to the degree necessary to have an impact on efficiency.

The picture for the EU 10 railways (and Croatia) is even harder to assess, partly because they are more recent members and, more important, because they were subjected to the wrenching transition from central planning to market structure, which would have had a devastating impact on both passenger and freight traffic no matter what changes in structure had occurred. With this said, it is at least interesting to point out that new, private freight operating companies are already carrying nearly 25 percent of freight traffic in Bulgaria and are carrying about 50 percent of the freight traffic in Romania. Clearly this would not have happened without vertical separation. It will be interesting to see if these companies eventually operate at higher levels of productivity and efficiency.

It is difficult to use the efficiency indices to draw any dispositive conclusions about the performance of DB AG and SNCF. They are both in the upper middle of the pack in size and outputs. Despite the emphasis on developing HSR services, SNCF has an average passenger trip of only $79 \mathrm{Km}$, while DB $\mathrm{AG}$ is even shorter at $40 \mathrm{Km}$, suggesting that the efficiency of both is heavily influenced by the economics of short haul passenger service. Well over 70 percent of SNCF's traffic output is passenger service while DB AG's passenger service ratio is in the high 40 percent range. In operations, though, 89 percent of SNCF's train-km are passengers and as are 75 percent of DB's operations: both railways are clearly using most of their capacity for passenger service, and (as with the U.S. and Japanese cases) when one service dominates, the others suffer for lack of priority access to capacity. Both are in the middle of the pack as to line traffic density, with DB AG slightly above SNCF. SNCF appears to make somewhat better use of its rolling stock fleet, though neither is at the top of the productivity rankings. However measured, the labor productivity of SNCF is lower than DB AG, although the productivity measures for both SNCF and DB AG (especially) are probably reduced by the inclusion of non-rail employees in the totals. ${ }^{18}$ SNCF reports a better Operating Ratio than DB AG in 2011, but this would not have been true in most of the earlier years reported. DB's average passenger fare is about 30 percent higher than SNCF, but its average freight tariff is about 10 percent lower than SNCF. SNCF's market share is higher than DB AG for passengers but lower for freight. SNCF's passenger traffic has grown slightly faster than DB AG's, but SNCF's performance in the freight market has been very poor, worse than DB AG and actually worse than the EU 10 countries. DB AG's improvement in labor productivity has been significantly better than SNCF, but neither did as well in

\footnotetext{
${ }^{18}$ SNCF would be raised by about 25 percent and DB nearly doubled if non-rail employees are excluded from the productivity measures. Unfortunately, though the data exist to do this separation in later years, the information is not available for earlier years.
} 
this index as any of the other railways listed in Table 12 (except Amtrak). Passenger tariffs on both SNCF and DB AG are higher than in 1990, by 50 percent for SNCF and 34 percent for DB AG. By comparison, both saw a significant reduction in freight tariffs since 1990.

It has been shown that vertical separation adds some costs of coordination and reporting as well as internal accounting and negotiation, although the exact degree of the added costs is around 5 percent or so. ${ }^{19}$ The counter question -- have these costs produced offsetting benefits, for example through added competition that reduces tariffs (as it did in the U.S.) certainly has an apparent answer: no for passengers and mixed for freight. Essentially every EU 15 and EU 10 railway has the same or higher passenger tariffs as in 2000 or 1995 . There is no discernable pattern in average freight tariffs, with some higher and some lower in 2011 than in 1995 or 2000.

The UK presents a significantly different picture. Although we defer to the paper by Nash and Smith to survey the UK case in more detail, Figures 4 and 5 give a useful picture in comparison with other EU experience. As shown in Figure 4, both passenger service and freight service reacted strongly to the restructuring, with passenger service reaching levels not seen since the end of World War II. In fact, as Table 11 shows, passenger service in the UK grew faster since the restructuring in 1995 than either SNCF or DB AG, and far faster than the EU 15 average. The same is true for freight in the UK The UK's rail market shares for both passenger and freight increased faster than the EU 15 average while the average passenger tariff has been nearly stable in constant terms.

There has been spirited debate in the economics academic community as to whether the positive UK rail results have been due to privatization or to restructuring or were primarily driven by strong GDP growth. This is an argument that cannot be resolved, but Figure 5 clearly shows that something positive happened upon reform: it would be very difficult to attribute all of the change to growth in the economy.

\footnotetext{
${ }^{19}$ See, e.g., Nash (2013), at pp. 6 and 7.
} 
Figure 4. Rail Traffic in the UK

$(000,000$ passenger-km and ton-km)

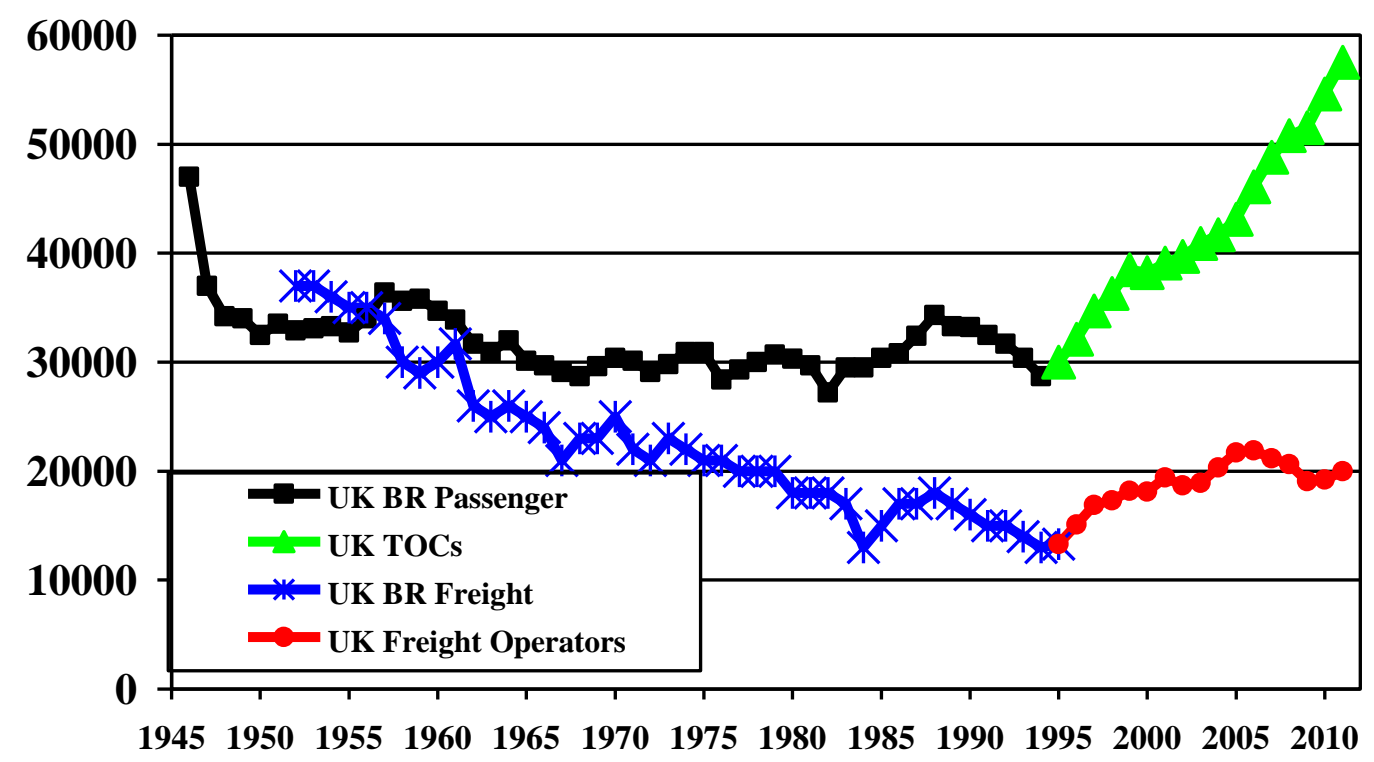

Source: SRA 2002c and SRA, 2003a, WDI, UIC, ORR.

Figure 5. UK Passenger-Km, Ton-Km and GDP

(Index, 1994=100, GDP index constant £1994-1995)

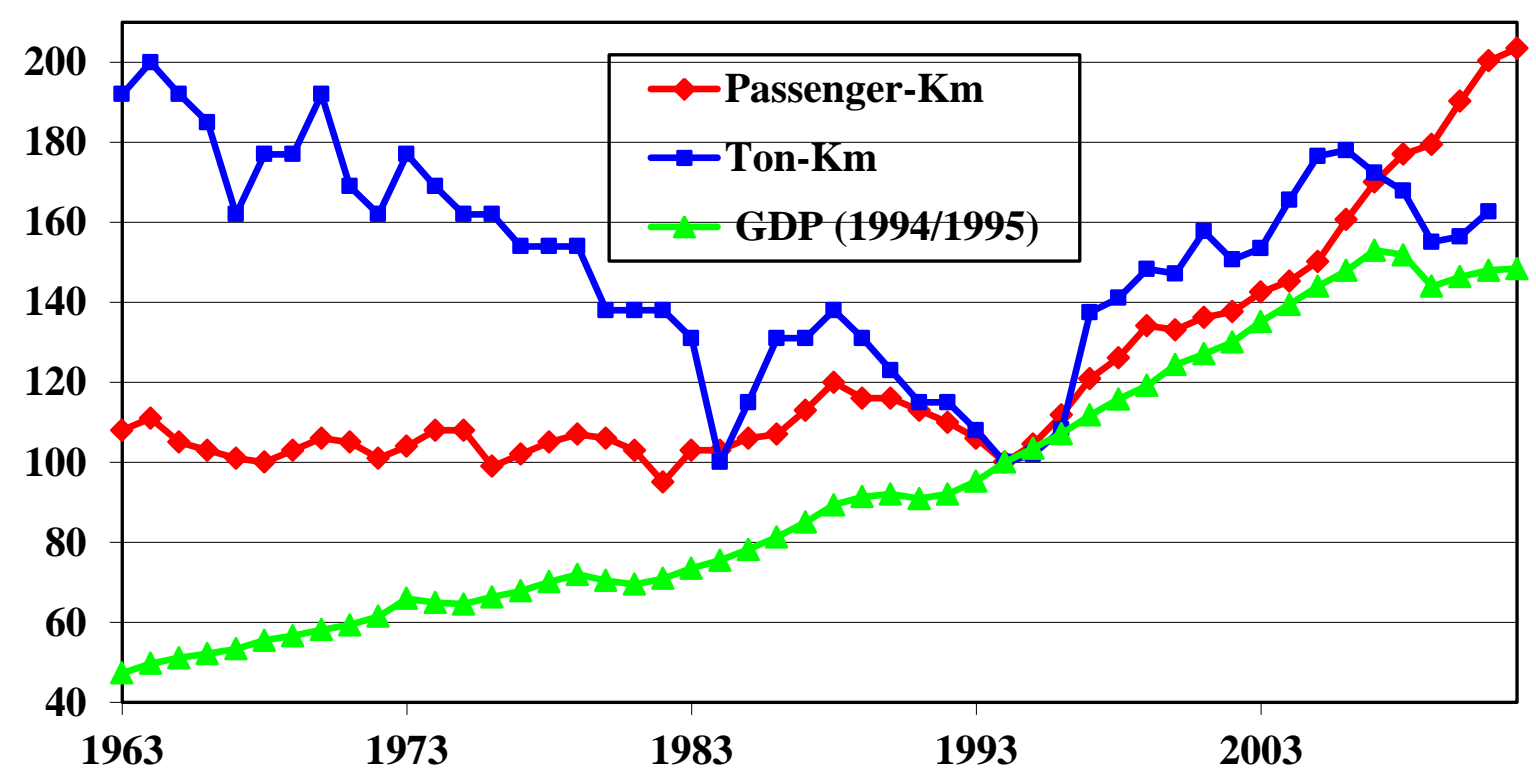

Source: SRA and UK Treasury website. 


\section{Conclusions}

No simple attempt to measure railway system efficiency can be expected to provide meaningful answers, both because the ambiguity and inherent challenge in defining what is meant by the term "efficiency" and because the structural complexity of rail organizations and the heterogeneity of railway services and offerings limits the value of any single index. Differing perceptions and purposes for attempts to measure "efficiency" will therefore require appropriate, tailored approaches

Among the various purposes for measuring "efficiency," the following need to be distinguished in particular:

- A government's interest to determine or monitor the overall performance of its railway system, e.g. with respect to value-for-money, modal competitiveness, operational cost-efficiency or financial viability;

- A government's policy analysis to define and review the success of railway restructuring or market organization initiatives;

- An audit of railway management performance (be it in a domestic or an international context);

- An inter-governmental policy evaluation and benchmarking effort

There are fundamental practical issues about "efficiency" measurement that need to be resolved before more high-level conceptual questions can effectively be addressed, including:

- Robust, internationally comparable reporting standards do not exist (note, while mandatory standards apply in the U.S. and Canada, Europe has nothing close to a homogeneous format. On a global scale, the UIC has the "best available" database, which could nevertheless be improved. In fact, though, the UIC's data may be at risk of losing quality and coverage;

- Transparency - Railways frequently resist reporting data to "their" governments, even when (and this appears to be the "default option" in Europe) substantial amounts of taxpayers' money is deployed to fund infrastructure and "public-service obligations"

- Off-Balance Sheet Items - Subsidies paid to railway systems are in many cases very substantial, but are not clearly reported. They typically come through one, or a combination of, infrastructure investment grants, passenger tariff surrogates and operations support and also special purpose vehicles for "legacy staff" obligations. Such items are often not included in railway balance-sheets and official reports, and these off-balance sheet items can have a strongly distorting effect on financial "efficiency" measurements

- Last but not least, definitions of parameters, be they rather of technical/operational, service performance or financial nature, often lack clarity and uniformity, which is a prerequisite for valid international comparisons 
As a consequence, and to the frustration of many industry observers, cross-sectional measurements of railway "efficiency" are often more subject to distortion and misunderstandings than meets the eye in the first place. This fact imposes a significant caveat on any interpretation of face-value comparative measurements. With this is mind, time-series evaluations can strongly buttress comparisons of how individual railways have developed over time and provide far greater reliability for interpretation. Even so, discontinuities in reporting or the organizational set-up of railways over time can also be a source of ambiguity (albeit less critical than in the case of cross-sectional comparisons)

From a "good public corporate governance" perspective, full reporting including "shadow assets" and financial flows to special purpose vehicles should be the norm. This is essential to give full accountability to the public on the deployment of funds and to inform policy makers responsibly.

Acknowledgment of the above mentioned limitations in data availability, quality and meaning leads to a cautious note on the use of econometric models to describe railway efficiency, for a number of reasons:

- Inconsistency of input data, including unclear definitions;

- Structural scarcity of data ("no big data") due to small and unstable samples of observed / observable railways systems, with inevitably inadequate sample sizes for statistical evaluations;

- An inability of econometric models to discriminate between "good" or "poor" corporate governance and management, which in practice can have an overriding impact on actual railway "efficiency";

- Most railway systems in the world show signs of protracted under-investment, especially in infrastructure, because "pro-forma" statements of steady-state investment requirements (i.e. future cash flows to be set aside) are rarely reported accurately. As a result, such backlogs go often undetected, leading to a real risk of a mis-assessment of the condition of infrastructure or other long-lived assets.

Qualified and informed judgment is always required in conjunction with even the best available and most sophisticated supporting "efficiency" measurement analyses. As a high level common denominator (an entry point) to measuring railway "efficiency," a balanced scorecard approach should be used that allows for some standardization and is broad enough to cover different aspects and measuring purposes in a 360 degree manner. A "Balanced Railway Efficiency Scorecard" (BRESC) should at least contain the following elements on a first-tier level (each and all open for greater indepth analysis):

- Scope of the railway system;

- Asset utilization of infrastructure and fleet;

- Human resource deployment;

- Operational Performance;

- Financials;

- Customer Centric Performance (i.e. performance in the market).

Railways are very asset intensive systems and economic analysis shows that under real-life conditions, asset utilization, which is highly disparate for different systems around the world has an major impact on overall system profitability or "efficiency". To a very large extent, asset utilization is a result of 
historically developed networks with vastly different traffic density coupled with above-rail operations that are more or less focused on sufficiently high demand services (where "demand" can have both a political as well as a market dimension). It is immediately and demonstrably clear that such disparate "operating conditions" affect railways' economics by orders of magnitude, asset utilization is therefore a structural determinant for a system's (in)ability to make profits or losses.

No other single factor is more important for economic railway "efficiency" than asset utilization. Hence, from an "efficiency" measurement purpose standpoint it is vitally important to separate the impact of those parameters that are primarily imposed by governments and other political stakeholders from those that are a good "proxy" for the performance of railway management.

A good and highly aggregate "efficiency" measurement from an overall perspective is railway market share ("modal share"); however, in cases where public subsidies are applied to provide services (the norm in Europe), subsidies can literally "buy" market share: thus, market share and system funding provisions need to be understood in close connection. As a direct result, "efficiency" measurements of a railway system may not suffice to describe the performance of railway management due to the overriding impact of economic "legacy factors" -- parameters, such as politics, which are exogenous to railway management.

Good proxies for direct management performance are the normalized full cost per train-kilometer in above-rail operations and the normalized full cost of maintaining and operating a unit piece of network infrastructure (e.g. a kilometer of line or a kilometer of track) in infrastructure management organizations. Various other dedicated or sometimes more global analyses exist to measure management performance in infrastructure and above rail operations, many of them in confidential or anonymous form, but it is not always clear that proper distinctions between what management can influence and what is given by "system legacy" are made. More work is needed if the effort to measure railway "efficiency" is to be promoted further.

Last but not least, almost all of the global railway "efficiency" measuring work is devoted to technical/operational and financial aspects and the customer perspective (which one could arguably consider the ultimate measure of "efficiency") appears to be a neglected area. Market-level questions to be analyzed are for instance, "how efficient is the travel or shipment solution offered by a railway in the eyes of the passenger or the shipper?" or "how competitive is the price of using a railway service as compared to other modes?" From a government perspective this also means to address aspects of public welfare.

There is reason to assume that the customer perspective has been neglected so far, because it poses a challenge to describe and measure; however this should not be an excuse, not to attempt it (note that emerging "big-data" applications may represent breakthrough opportunities to capture customercentric information)

Looking at the data and indices, per se, it is clear that the policy and structural changes in U.S., Canada and Japan worked in almost all dimensions and one can strongly argue that the changes would not have occurred absent the reforms.

It is far beyond the scope of this paper to review all of the EU railways individually. The experience in the EU is much more complex because most services at base are social rather than commercial, legitimately increasing the role of government, and there is no good annual reporting on the value of 
social benefits and costs generated by the railways. ${ }^{20}$ The result was a much less clear definition of objectives and incentives along with unstable, often inadequate financial support reflecting the vicissitudes of annual public budgeting. Attempts to change the situation were impeded by political resistance from unions and other interest groups and, in many cases, a complete lack of transparency of the actual performance ("efficiency") of the railway that made scrutiny by the public, including the academic sector, impossible. We also have to deal with the null hypothesis - what would have happened without reform -- though SNCF performance may give an indication. It is also possible to argue that DB AG has resisted the actual implementation of most of the significant aspects of the EU's reform objectives, at least with respect to railway structure in Germany.

It seems clear that the UK government overshot its target by smashing the old BR and privatizing it completely at the outset: but, gradual reform since 1995 has produced a system that certainly seems better than the old BR. In France, the attempts to reform (without actually doing so) have clearly not been very productive. RFF never fully emerged from SNCF control, and recombining them into a new agency will mostly have the effect of turning back the clockl. The DBAG holding company approach produced a conflict of interest between DB Netz and the operators vis a vis potential entrants, a conflict that will remain until DB Netz is truly separated.

${ }^{20}$ This information could be added to other reporting requirements, at least in a prescribed, approximate form. 
Annex 1

TABLES 
Table 1. Sample Key

\begin{tabular}{|c|c|c|c|}
\hline Country & $\begin{array}{l}\text { Railway name and } \\
\text { date of inception }\end{array}$ & Country & $\begin{array}{l}\text { Railway name and } \\
\text { date of inception }\end{array}$ \\
\hline \multicolumn{2}{|r|}{ EU 15} & \multicolumn{2}{|c|}{ EU $10+$ Croatia } \\
\hline \multirow{2}{*}{ Austria } & GKB & \multirow{6}{*}{ Bulgaria } & BDZ \\
\hline & ÖBB & & BDZP \\
\hline Belgium & SNCB/NMBS & & BDZ Cargo \\
\hline \multirow{2}{*}{ Denmark } & DSB & & NRIC (2003) \\
\hline & BDK (1997) & & BRC \\
\hline \multirow{2}{*}{ Finland } & VR & & Bulmarket \\
\hline & RHK/FTA (1995) & \multirow{2}{*}{ Czech Republic } & CD (2003) \\
\hline \multirow{3}{*}{ France } & SNCF & & SZDC (2003) \\
\hline & RFF (1997) & \multirow{3}{*}{ Slovakia } & ZSSK \\
\hline & Veolia & & ZSSK Cargo \\
\hline DB Germany & Prior to reunification & & ZSR (2002) \\
\hline DR Germany & Prior to reunification & Former Czech. & CSD (End 1992) \\
\hline Germany & DBAG (1994) & Estonia & EVR \\
\hline Greece & OSE & \multirow{5}{*}{ Hungary } & Floyd \\
\hline Ireland & $\mathrm{CIE}$ & & Gysev \\
\hline \multirow{2}{*}{ Italy } & FNM & & MAV \\
\hline & FS & & MAV Cargo (2006) \\
\hline \multirow{2}{*}{ Luxembourg } & CFL & & MAV Start (2007) \\
\hline & CFL Cargo (2007) & Latvia & LDZ \\
\hline \multirow{2}{*}{ Netherlands } & NS & Lithuania & LG \\
\hline & Pro Rail (1998) & Poland & PKP \\
\hline \multirow{3}{*}{ Portugal } & $\mathrm{CP}$ & \multirow{8}{*}{ Romania } & CFR \\
\hline & CP Carga & & CFR Calatori (2006) \\
\hline & REFER (1997) & & CFR MARFA (2006) \\
\hline \multirow{5}{*}{ Spain } & RENFE & & CFR SA (2006) \\
\hline & ADIF (2005) & & GFR \\
\hline & Euskotren & & Servtrans \\
\hline & FEVE & & TFG \\
\hline & FGC & & Unifertrans \\
\hline \multirow{3}{*}{ Sweden } & SJ & Slovenia & SZ \\
\hline & Green Cargo (2002)) & Croatia & $\mathrm{HZ}$ \\
\hline & BV/Trafikverket (1988) & \multicolumn{2}{|c|}{ Other Railways } \\
\hline \multirow{5}{*}{$\begin{array}{l}\text { United } \\
\text { Kingdom }\end{array}$} & $\mathrm{BR}$ & \multirow{2}{*}{ United States } & Class I \\
\hline & ATOC (1995) & & Amtrak (1972) \\
\hline & Freight (1995) & \multirow{2}{*}{ Canada } & Freight \\
\hline & Railtrack/NR (1995) & & VIA (1980) \\
\hline & NIR & China & $\mathrm{CR}$ \\
\hline & & Japan & All \\
\hline & & India & $\mathrm{IR}$ \\
\hline & & \multicolumn{2}{|c|}{ Norway and Switzerland } \\
\hline & & & NSB \\
\hline & & Norway & Cargonet (2002) \\
\hline & & & JBV (1996) \\
\hline & & & BLS \\
\hline & & Switzerland & BLS Cargo \\
\hline & & & SBB/CFF/FFS \\
\hline
\end{tabular}




\begin{tabular}{|c|c|c|c|c|c|c|c|}
\hline \multirow{2}{*}{\multicolumn{8}{|c|}{$\begin{array}{ll}\text { Table } 2 \\
\end{array}$}} \\
\hline \multicolumn{3}{|c|}{ Basic Indicators of Size and Scale of Operations of Railways in the Overall Sample (2011 data) } & & & & & \\
\hline EU15 & EU10 & $\mathrm{CH} / \mathrm{NO}$ & All Other & & & & \\
\hline Railway & Employees & Railway & Line $\mathrm{Km}$ & Railway & Pax Km & Railway & Tonne-Km \\
\hline$C R$ & 2051100 & US Class I & 153249 & IR & 978508 & CR & 2562635 \\
\hline IR & 1328000 & CR & 66041 & CR & 815699 & US Class I & 2526444 \\
\hline US Class I & 158623 & IR & 64460 & Japan & 245612 & IR & 625723 \\
\hline SNCF & 139501 & Canada Frt & 52002 & SNCF & 86094 & Canada Frt & 372264 \\
\hline DBAG & 137482 & Amtrak & 37000 & DBAG & 77567 & DBAG & 111980 \\
\hline Japan & 127900 & DBAG & 33570 & ATOC & 57500 & PKP & 37189 \\
\hline$P K P$ & 100942 & RFF & 29616 & FS & 39368 & Green Cargo & 24000 \\
\hline FS & 76417 & Japan & 20131 & RENFE & 21398 & SNCF & 23241 \\
\hline ATOC & 49405 & $P K P$ & 19725 & SBB/CFF/FFS & 17156 & Japan & 20256 \\
\hline ӧвв & 45352 & FS & 16726 & NS & 16808 & UK Freight & 20000 \\
\hline MAV & 37034 & Network Rail & 15759 & $P K P$ & 15740 & ӧвB & 16890 \\
\hline SNCB/NMBS & 36453 & ADIF & 13945 & SNCB/NMBS & 10848 & $\angle D Z$ & 16550 \\
\hline Network Rail & 34130 & VIA & 13490 & Amtrak & 10331 & $L G$ & 15088 \\
\hline Canada Frt & 33106 & CFR & 10777 & ӧвB & 10300 & $C D$ & 12123 \\
\hline$C D$ & 31846 & BV/Trafik. & 10014 & DSB & 10102 & FS & 11547 \\
\hline SBB/CFF/FFS & 28586 & SZDC & 9470 & $C D$ & 6635 & VR & 9395 \\
\hline CFR SA & 23951 & MAV & 7387 & SJ & 6381 & MAV Cargo & 8000 \\
\hline Amtrak & 20047 & RHK/FTA & 5944 & MAVStart & 5561 & SBB/CFF/FFS & 7656 \\
\hline ZSR & 15820 & ÖвB & 4826 & CFR Calatori & 4814 & RENFE & 7564 \\
\hline CFR Calatori & 14269 & $\mathrm{JBV}$ & 4154 & VR & 3882 & ZSSK Cargo & 7290 \\
\hline RENFE & 13955 & NRIC & 4072 & CP & 3750 & CFR MARFA & 6658 \\
\hline NRK & 13825 & ZSR & 3624 & NSB & 2663 & SNCB/NMBS & 5500 \\
\hline ADIF & 13433 & SNCB/NMBS & 3578 & ZSSK & 2413 & NS & 5000 \\
\hline$H Z$ & 12468 & SBB/CFF/FFS & 3040 & $B D Z$ & 2068 & EVR & 5000 \\
\hline$L D Z$ & 11665 & Pro Rail & 2886 & CIE & 1638 & GFR & 4805 \\
\hline SZDC & 11631 & REFER & 2794 & $H Z$ & 1486 & sz & 3584 \\
\hline$B D Z$ & 10637 & $H Z$ & 2722 & VA & 1369 & Cargonet & 3000 \\
\hline$L G$ & 10505 & OSE & 2534 & OSE & 1300 & $B D Z$ & 2497 \\
\hline \begin{tabular}{|l|} 
CFR MARFA \\
\end{tabular} & 9145 & BDK & 2130 & FNM & 1100 & $H Z$ & 2438 \\
\hline VR & 8967 & CIE & 1919 & BLS & 865 & CP Carga & 2064 \\
\hline$s z$ & 8886 & $L D Z$ & 1864 & FGC & 821 & DSB & 1800 \\
\hline ZSSK Cargo & 8701 & $L G$ & 1767 & sz & 773 & BLS Cargo & 1104 \\
\hline DSB & 8084 & sz & 1209 & $L G$ & 389 & Servtrans & 781 \\
\hline NS & 7653 & FEVE & 1192 & CFL & 349 & Gysev & 775 \\
\hline BV/Trafik. & 6758 & EVR & 792 & Euskotren & 279 & $B R C$ & 671 \\
\hline ZSSK & 4862 & BLS & 430 & $E V R$ & 243 & CFR SA & 614 \\
\hline CIE & 4198 & FNM & 318 & Gysev & 200 & OSE & 500 \\
\hline Pro Rail & 3954 & Gysev & 284 & FEVE & 183 & FEVE & 388 \\
\hline JBV & 3600 & CFL & 275 & $L D Z$ & 84 & Unifertrans & 362 \\
\hline OSE & 3262 & FGC & 270 & & & CFL Cargo & 200 \\
\hline REFER & 3237 & Euskotren & 226 & & & Bulmarket & 123 \\
\hline Green Cargo & 3200 & & & & & CIE & 105 \\
\hline NSB & 3183 & & & & & FGC & 49 \\
\hline $\mathrm{CP}$ & 3132 & & & & & & \\
\hline CFL & 3077 & & & & & & \\
\hline SJ & 3037 & & & & & & \\
\hline MA & 2899 & & & & & & \\
\hline BLS & 2722 & & & & & & \\
\hline GFR & 2603 & & & & & & \\
\hline FNM & 2200 & & & & & & \\
\hline BDK & 2000 & & & & & & \\
\hline FEVE & 1957 & & & & & & \\
\hline EVR & 1796 & & & & & & \\
\hline Gysev & 1354 & & & & & & \\
\hline RFF & 1353 & & & & & & \\
\hline FGC & 1298 & & & & & & \\
\hline Euskotren & 863 & & & & & & \\
\hline Servtrans & 792 & & & & & & \\
\hline CP Carga & 665 & & & & & & \\
\hline Unifertrans & 270 & & & & & & \\
\hline$B R C$ & 253 & & & & & & \\
\hline TFG & 130 & & & & & & \\
\hline RHKJFTA & 120 & & & & & & \\
\hline Bulmarket & 80 & & & & & & \\
\hline BLS Carge & 79 & & & & & & \\
\hline & & & & & & & \\
\hline Source: See A & pendix $A$ & & & & & & \\
\hline
\end{tabular}


Table 3. Average Length of Haul (Km) (2011 data)

\begin{tabular}{|c|c|c|c|}
\hline EU15 & EU10 & $\mathrm{CH} / \mathrm{NO}$ & All Other \\
\hline Railway & Passenger & Railway & Freight \\
\hline CR & 529 & US Class I & 1477 \\
\hline Amtrak & 355 & Canada Frt & 1199 \\
\hline VIA & 331 & CR & 805 \\
\hline$L D Z$ & 250 & IR & 679 \\
\hline SJ & 205 & Japan & 654 \\
\hline IR & 128 & CFR SA & 483 \\
\hline CFR Calatori & 90 & RENFE & 437 \\
\hline OSE & 87 & GFR & 392 \\
\hline PKP & 85 & SNCF & 371 \\
\hline$L G$ & 84 & Green Cargo & 353 \\
\hline SNCF & 79 & $B R C$ & 324 \\
\hline FS & 75 & DBAG & 318 \\
\hline$B D Z$ & 71 & $L G$ & 288 \\
\hline VR & 57 & $L D Z$ & 279 \\
\hline NS & 54 & FS & 276 \\
\hline ZSSK & 53 & VR & 270 \\
\hline NSB & 52 & $P K P$ & 265 \\
\hline EVR & 51 & Bulmarket & 259 \\
\hline MAV Start & 50 & DSB & 240 \\
\hline ÖBB & 49 & BLS Cargo & 237 \\
\hline$S Z$ & 49 & Unifertrans & 237 \\
\hline SBB/CFF/FFS & 49 & CP Carga & 226 \\
\hline SNCB/NMBS & 47 & Freight & 222 \\
\hline DSB & 46 & $S z$ & 220 \\
\hline RENFE & 46 & $B D Z$ & 215 \\
\hline CIE & 44 & Servtrans & 207 \\
\hline Gysev & 41 & $H Z$ & 207 \\
\hline DBAG & 40 & $E V R$ & 200 \\
\hline$C D$ & 40 & MAV Cargo & 200 \\
\hline ATOC & 39 & ÖBB & 199 \\
\hline$H Z$ & 30 & ZSSK Cargo & 194 \\
\hline CP & 30 & Floyd & 190 \\
\hline Japan & 28 & $C D$ & 182 \\
\hline FEVE & 21 & CFR MARFA & 181 \\
\hline CFL & 19 & CIE & 172 \\
\hline$\underline{B L S}$ & 17 & $\underline{\text { SBB/CFF/FFS }}$ & 163 \\
\hline Euskotren & 11 & OSE & 147 \\
\hline FGC & 10 & FEVE & 142 \\
\hline \multirow{4}{*}{\multicolumn{2}{|c|}{ Source: See Appendix A. }} & Gysev & 141 \\
\hline & & SNCB/NMBS & 138 \\
\hline & & FGC & 63 \\
\hline & & CFL Cargo & 32 \\
\hline
\end{tabular}


Table 4

Passenger Shares (\%) Measured by

\begin{tabular}{|c|c|c|c|c|c|}
\hline \multicolumn{6}{|c|}{ Passenger Shares (\%) Measured by } \\
\hline EU15 & EU10 & $\mathrm{CH} / \mathrm{NO}$ & All Other & & \\
\hline & $\%$ of TU & & $\begin{array}{c}\text { \% of } \\
\text { Gross } \\
\text { Tonne- } \\
\text { Km }\end{array}$ & & $\begin{array}{c}\% \text { of } \\
\text { Train-Km }\end{array}$ \\
\hline ZSSK & 100 & CIE & 100 & DSB & 100 \\
\hline MAV Start & 100 & FNM & 100 & NS & 100 \\
\hline Amtrak & 100 & NS & 100 & ZSSK & 100 \\
\hline VIA & 100 & NIR & 100 & MAV Start & 100 \\
\hline NSB & 100 & ZSSK & 100 & Amtrak & 100 \\
\hline Euskotren & 100 & MAV Start & 100 & VIA & 100 \\
\hline FGC & 94 & VIA & 100 & Euskotren & 100 \\
\hline CIE & 94 & NSB & 100 & FGC & 98 \\
\hline Japan & 92 & Euskotren & 98 & CIE & 98 \\
\hline DSB & 85 & FGC & 93 & Japan & 92 \\
\hline SNCF & 79 & Japan & 81 & SNCB/NMBS & 89 \\
\hline FS & 77 & SNCF & 73 & CFL & 89 \\
\hline NS & 77 & RENFE & 70 & SNCF & 89 \\
\hline ATOC & 74 & SNCB/NMBS & 67 & RENFE & 88 \\
\hline RENFE & 74 & CP & 62 & FEVE & 88 \\
\hline OSE & 72 & SBB/CFF/FFS & 61 & FS & 88 \\
\hline SBB/CFF/FFS & 69 & CFL & 59 & OSE & 87 \\
\hline SNCB/NMBS & 66 & FEVE & 49 & SBB/CFF/FFS & 83 \\
\hline CP & 64 & $B D Z$ & 46 & CP & 82 \\
\hline CFL & 64 & SJ & 46 & $C D$ & 82 \\
\hline IR & 61 & $C D$ & 43 & $B D Z$ & 75 \\
\hline BLS & 44 & Gysev & 42 & $H Z$ & 75 \\
\hline DBAG & 41 & DBAG & 42 & DBAG & 75 \\
\hline$B D Z$ & 39 & $H Z$ & 35 & CFR Calatori & 74 \\
\hline ÖBB & 38 & IR & 35 & Gysev & 74 \\
\hline$H Z$ & 38 & VR & 35 & BLS & 73 \\
\hline$C D$ & 35 & CFR Calatori & 34 & VR & 70 \\
\hline FEVE & 32 & ATOC & 33 & $P K P$ & 69 \\
\hline$P K P$ & 30 & ÖBB & 32 & ÖBB & 69 \\
\hline VR & 29 & BLS & 31 & IR & 64 \\
\hline CFR Calatori & 28 & $P K P$ & 24 & $S Z$ & 60 \\
\hline CR & 24 & $S Z$ & 19 & CR & 44 \\
\hline SJ & 21 & CR & 17 & EVR & 38 \\
\hline Gysev & 21 & $L G$ & 4 & $L G$ & 36 \\
\hline$s Z$ & 18 & EVR & 4 & Servtrans & 15 \\
\hline EVR & 5 & $L D Z$ & 1 & US Class I & 7 \\
\hline$L G$ & 3 & Canada Frt & 1 & $L D Z$ & 6 \\
\hline$L D Z$ & 1 & & & & \\
\hline US Class I & 1 & & & & \\
\hline Source: See & endix $A$ & & & & \\
\hline
\end{tabular}


Table 5

Measures of Line Traffic Density (2011 data)

\begin{tabular}{|c|c|c|c|c|c|}
\hline EU15 & EU10 & $\underline{\mathrm{CH} / \mathrm{NO}}$ & All Other & & \\
\hline & $\begin{array}{c}\text { TU/Km } \\
(000)\end{array}$ & & $\begin{array}{c}\text { Gross T- } \\
\mathrm{Km} / \mathrm{Km} \\
(000)\end{array}$ & & $\begin{array}{c}\text { Train- } \\
\mathrm{Km} / \mathrm{Km}\end{array}$ \\
\hline CR & 51155 & CR & 72238 & SBB/CFF/FFS & 45663 \\
\hline IR & 24887 & US Class I & 29585 & NS & 39369 \\
\hline US Class I & 16553 & IR & 24356 & FGC & 38007 \\
\hline Japan & 13207 & SBB/CFF/FFS & 24342 & Japan & 37355 \\
\hline$L D Z$ & 8924 & $E V R$ & 17249 & BLS & 37072 \\
\hline$L G$ & 8759 & $L G$ & 16365 & CFL & 32724 \\
\hline SBB/CFF/FFS & 8162 & $L D Z$ & 15510 & UK & 32631 \\
\hline NS & 7556 & Japan & 13853 & CR & 30817 \\
\hline Canada Frt & 7185 & ӦВB & 13749 & FNM & 28346 \\
\hline EVR & 6620 & Canada Frt & 12930 & ӦВB & 28212 \\
\hline DBAG & 5646 & DBAG & 11703 & DSB & 27809 \\
\hline ÖBB & 5634 & NS & 11499 & DBAG & 25772 \\
\hline DSB & 5588 & SNCB/NMBS & 10900 & SNCB/NMBS & 24427 \\
\hline UK & 4918 & CFL & 8844 & Euskotren & 23367 \\
\hline SNCB/NMBS & 4569 & BLS & 6977 & Gysev & 18824 \\
\hline SNCF & 3692 & SNCF & 6970 & FS & 16474 \\
\hline$s Z$ & 3604 & Gysev & 6810 & $s Z$ & 16443 \\
\hline FNM & 3459 & $s Z$ & 6699 & SNCF & 15659 \\
\hline Gysev & 3433 & ZSSK & 5832 & $C D$ & 15598 \\
\hline FGC & 3222 & FNM & 5346 & IR & 14629 \\
\hline FS & 3044 & FGC & 5293 & RENFE & 13087 \\
\hline$P K P$ & 2683 & $P K P$ & 5289 & MAV & 12574 \\
\hline ZSSK & 2677 & VR & 4937 & CP & 12554 \\
\hline VR & 2234 & $C D$ & 4784 & ZSSK & 11591 \\
\hline CP & 2081 & RENFE & 4545 & $H Z$ & 9102 \\
\hline RENFE & 2077 & UK & 3996 & CIE & 9051 \\
\hline BLS & 2012 & CP & 3761 & $L G$ & 8671 \\
\hline CFL & 1996 & CFR & 3495 & $P K P$ & 8645 \\
\hline$C D$ & 1981 & MAV & 3374 & VR & 8592 \\
\hline MAV & 1836 & Euskotren & 3133 & EVR & 8415 \\
\hline CFR & 1616 & $H Z$ & 2868 & FEVE & 8270 \\
\hline$H Z$ & 1442 & $B D Z$ & 2289 & OSE & 8208 \\
\hline$B D Z$ & 1316 & FS & 1495 & $B D Z$ & 7737 \\
\hline Euskotren & 1235 & CIE & 1407 & CFR & 7578 \\
\hline CIE & 908 & FEVE & 1102 & $L D Z$ & 5293 \\
\hline OSE & 710 & Amtrak & 1047 & US Class I & 4491 \\
\hline FEVE & 479 & OSE & 1026 & Amtrak & 1629 \\
\hline Amtrak & 279 & JBV & 849 & VIA & 785 \\
\hline VIA & 101 & VIA & 321 & Canada Frt & 204 \\
\hline
\end{tabular}

Source: See Appendix A 
Table 6

Measures of Productivity of Rolling Stock (2011 data)

\begin{tabular}{|l|l|l|l|}
\hline EU15 & EU10 & $\mathrm{CH} / \mathrm{NO}$ & All Other \\
\hline
\end{tabular}

\begin{tabular}{|c|c|c|c|c|c|}
\hline Railway & $\begin{array}{c}\text { Passenger- } \\
\text { Km/Coach + } \\
\text { MUs }\end{array}$ & Railway & $\begin{array}{c}\text { Tonne- } \\
\text { Km/Wagon }\end{array}$ & Railway & $\begin{array}{c}\text { TU/Locomotive } \\
\text { + adjusted } \\
\text { Mus* }\end{array}$ \\
\hline IR & 223404 & Gysev & 8424 & IR & 178950 \\
\hline CR & 60049 & \begin{tabular}{|c|} 
Canada Frt * \\
\end{tabular} & 5429 & CR & 172449 \\
\hline SBB/CFF/FFS & 47132 & CR & 3983 & Japan & 159473 \\
\hline Japan & 44820 & Green Cargo & 3429 & Canada Frt & 134780 \\
\hline SJ & 35450 & IR & 3276 & SJ & 104038 \\
\hline CFR Calatori & 20227 & $L D Z$ & 2702 & US Class I & 102161 \\
\hline DSB & 18434 & Japan & 2328 & DSB & 83231 \\
\hline$B D Z$ & 14563 & $B R C$ & 2207 & $L D Z$ & 82347 \\
\hline FS & 14399 & US Class I & 2005 & Green Cargo & 76190 \\
\hline SNCF & 14170 & GFR & 1848 & MAV Start & 75489 \\
\hline$H Z$ & 13759 & EVR & 1677 & EVR & 69907 \\
\hline VR & 11155 & $L G$ & 1634 & $L G$ & 58294 \\
\hline Gysev & 11111 & SNCF & 1144 & RENFE & 56566 \\
\hline Amtrak & 8777 & $S Z$ & 1141 & NS & 55942 \\
\hline $\mathrm{CP}$ & 8601 & DBAG & 1049 & CP Carga & 46909 \\
\hline ÖBB & 7768 & ÖBB & 958 & NSB & 40146 \\
\hline$P K P$ & 7301 & SBB/CFF/FFS & 925 & FGC & 29326 \\
\hline SNCB/NMBS & 7251 & VR & 907 & ATOC & 28975 \\
\hline$L G$ & 6707 & MAV Cargo & 727 & SNCF & 28931 \\
\hline ZSSK & 6557 & CP Carga & 651 & DBAG & 27558 \\
\hline MAV Start & 6277 & Unifertrans & 635 & VR & 26741 \\
\hline OSE & 5078 & RENFE & 613 & $B R C$ & 25808 \\
\hline CFL & 4847 & $P K P$ & 571 & SNCB/NMBS & 25438 \\
\hline$C D$ & 4570 & Bulmarket & 542 & Floyd & 24300 \\
\hline EVR & 4500 & $B D Z$ & 514 & $S Z$ & 23962 \\
\hline FGC & 3873 & SNCB/NMBS & 500 & BLS Cargo & 22080 \\
\hline BLS & 3794 & Servtrans & 485 & $\mathrm{CP}$ & 21887 \\
\hline DBAG & 3778 & $C D$ & 444 & Gysev & 21429 \\
\hline NS & 3560 & FS & 405 & GFR & 21167 \\
\hline ATOC & 2677 & $H Z$ & 402 & ÖBB & 20711 \\
\hline CIE & 2452 & \begin{tabular}{|l} 
FEVE \\
\end{tabular} & 340 & FS & 18742 \\
\hline FNM & 2444 & FGC & 239 & $\mathrm{CIE}$ & 18220 \\
\hline NSB & 2245 & $\mathrm{CIE}$ & 209 & SBB/CFF/FFS & 17791 \\
\hline VIA & 1720 & CFR MARFA & 167 & $P K P$ & 16133 \\
\hline$S Z$ & 1528 & OSE & 158 & $H Z$ & 15812 \\
\hline Euskotren & 1125 & CFL Cargo & 51 & Unifertrans & 12067 \\
\hline \multirow[t]{15}{*}{$L D Z$} & 420 & Euskotren & 3 & FNM & 11640 \\
\hline & & & & FEVE & 10774 \\
\hline & & & & $B D Z$ & 10666 \\
\hline & & & & $C D$ & 10451 \\
\hline & & & & ZSSK Cargo & 10353 \\
\hline & & & & ZSSK & 9923 \\
\hline & & & & OSE & 9262 \\
\hline & & & & VIA & 9229 \\
\hline & & & & CFL & 9184 \\
\hline & & & & Euskotren & 9152 \\
\hline & & & & Bulmarket & 8786 \\
\hline & & & & CFR MARFA & 7671 \\
\hline & & & & BLS & 7588 \\
\hline & & & & CFR Calatori & 5762 \\
\hline & & & & CFL Cargo & 3448 \\
\hline
\end{tabular}

* Canada's apparent high productivity may be due to exclusion of non-railway owned wagons. Source: See Appendix A 


\begin{tabular}{|c|c|c|c|c|c|}
\hline \multicolumn{6}{|c|}{ Table 7} \\
\hline \multicolumn{6}{|c|}{ Indicators of Output per Employee (2011 data) } \\
\hline EU15 & EU10 & $\underline{\mathrm{CH} / \mathrm{NO}}$ & All Other & & \\
\hline Railway & \begin{tabular}{|l|} 
TU/ \\
Employee \\
$(000)$ \\
\end{tabular} & Railway & \begin{tabular}{|l|} 
GT-Km/ \\
Employee \\
$(000)$ \\
\end{tabular} & Railway & $\begin{array}{l}\text { Train-Km/ } \\
\text { Employee }\end{array}$ \\
\hline US Class I & 15927 & US Class I & 28339 & NS & 14846 \\
\hline \begin{tabular}{|l|} 
Canada Frt \\
\end{tabular} & 11245 & Canada Frt & 20179 & SJ & 13303 \\
\hline Green Cargo & 7500 & Green Cargo & 7813 & RENFE & 13078 \\
\hline Floyd & 3857 & EVR & 7606 & ATOC & 10408 \\
\hline CP Carga & 3104 & SJ & 6915 & CP Carga & 9335 \\
\hline$E V R$ & 2919 & CP Carga & 6027 & $\mathrm{CP}$ & 9217 \\
\hline NS & 2850 & $B R C$ & 4593 & NSB & 8840 \\
\hline$B R C$ & 2652 & RENFE & 4541 & NIR & 7931 \\
\hline SJ & 2101 & NS & 4336 & FGC & 7906 \\
\hline \begin{tabular}{|l|} 
Japan \\
\end{tabular} & 2079 & Floyd & 3857 & DSB & 7327 \\
\hline RENFE & 2075 & VR & 3272 & OSE & 6376 \\
\hline GFR & 1846 & GFR & 3069 & ZSSK & 6319 \\
\hline CR & 1647 & DBAG ** & 2857 & DBAG ** & 6292 \\
\hline Bulmarket & 1538 & $L G$ & 2753 & Floyd & 6222 \\
\hline VR & 1481 & SBB/CFF/FFS & 2589 & Euskotren & 6119 \\
\hline$L G$ & 1473 & Unifertrans & 2574 & Japan & 5880 \\
\hline DSB & 1472 & $L D Z$ & 2478 & SBB/CFF/FFS & 5868 \\
\hline$L D Z$ & 1426 & $\mathrm{CR}$ & 2326 & BLS & 5856 \\
\hline DBAG ** & 1378 & Japan & 2180 & VR & 5695 \\
\hline \begin{tabular}{|l|} 
Unifertrans \\
\end{tabular} & 1341 & $\mathrm{CP}$ & 2075 & FEVE & 5037 \\
\hline IR & 1208 & NSB & 2007 & US Class I & 5007 \\
\hline CP & 1197 & Servtrans & 1948 & $C D$ & 4638 \\
\hline ATOC & 1164 & Amtrak & 1932 & CFR Calatori & 4260 \\
\hline Servtrans & 986 & ZSSK Cargo & 1682 & CIE & 4137 \\
\hline$\underline{\mathrm{SBB} / \mathrm{CFF} / \mathrm{FFS}}$ & 868 & CFR MARFA & 1607 & FNM & 4097 \\
\hline ZSSK Cargo & 838 & Bulmarket & 1538 & Gysev & 3948 \\
\hline NSB & 837 & VIA & 1494 & $B R C$ & 3806 \\
\hline SNCF * & 784 & SNCF * & 1480 & EVR & 3711 \\
\hline \begin{tabular}{|l|} 
CFR MARFA \\
\end{tabular} & 728 & ÖBB & 1463 & VIA & 3652 \\
\hline Gysev & 720 & Gysev & 1428 & FS & 3606 \\
\hline FGC & 670 & $C D$ & 1423 & SNCF * & 3326 \\
\hline FS & 666 & ZSSK & 1337 & Bulmarket & 3225 \\
\hline ÖBB & 600 & NIR & 1213 & Amtrak & 3007 \\
\hline$C D$ & 589 & IR & 1182 & ÖBB & 3002 \\
\hline OSE & 552 & BLS & 1102 & $B D Z$ & 2847 \\
\hline$P K P$ & 524 & FGC & 1101 & GFR & 2471 \\
\hline Amtrak & 515 & SNCB/NMBS & 1070 & SNCB/NMBS & 2398 \\
\hline FNM & 500 & $P K P$ & 1033 & $s z$ & 2237 \\
\hline ZSSK & 496 & JBV & 980 & Servtrans & 2091 \\
\hline$S Z$ & 490 & $s z$ & 911 & $H Z$ & 1987 \\
\hline VIA & 472 & CFR Calatori & 893 & Unifertrans & 1922 \\
\hline SNCB/NMBS & 448 & Euskotren & 820 & $P K P$ & 1689 \\
\hline$B D Z$ & 429 & OSE & 797 & $L G$ & 1459 \\
\hline CIE & 415 & FNM & 773 & CFR MARFA & 1370 \\
\hline \begin{tabular}{|l|} 
NIR \\
\end{tabular} & 354 & $B D Z$ & 755 & ZSSK Cargo & 1297 \\
\hline CFR Calatori & 337 & FEVE & 671 & CR & 992 \\
\hline \begin{tabular}{|l|} 
Euskotren \\
\end{tabular} & 323 & CIE & 643 & $L D Z$ & 846 \\
\hline BLS & 318 & $H Z$ & 626 & IR & 710 \\
\hline$H Z$ & 315 & ATOC & 425 & & \\
\hline FEVE & 292 & FS & 327 & & \\
\hline CFR SA & 26 & & & & \\
\hline \multicolumn{6}{|c|}{ * SNCF adjusted for non-rail employees (1.079) } \\
\hline \multicolumn{6}{|c|}{ ** DB AG adjusted for non-rail employees (2.053) } \\
\hline Source: See $A$ & ppendix A & & & & \\
\hline
\end{tabular}




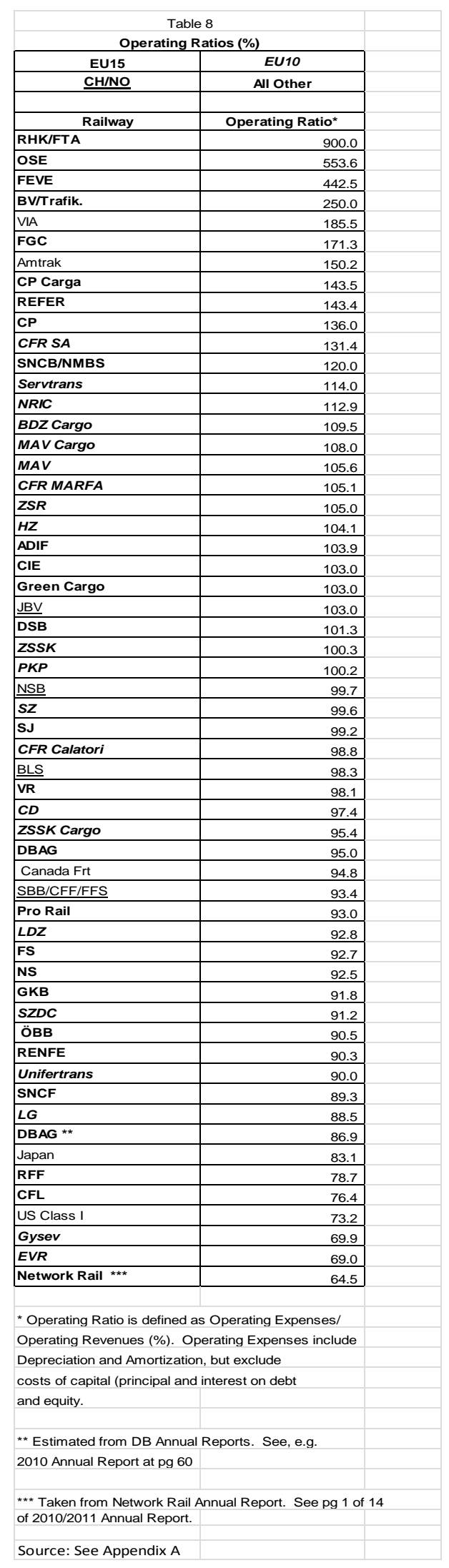


Table 9

Average Revenues Expressed as Constant 2011 US PPP \$ per Passenger-Km or per Tonne-Km

\begin{tabular}{|l|c|}
\hline \multicolumn{4}{|c}{ Passenger-Km or per Tonne-Km } \\
\hline EU15 & EU10 \\
\hline
\end{tabular}

\begin{tabular}{|l|r|}
\hline Railway & $\begin{array}{c}\text { Average } \\
\text { Passenger } \\
\text { Revenue/ } \\
\text { Passenger-Km }\end{array}$ \\
\hline CFL & 0.7520 \\
\hline
\end{tabular}

\begin{tabular}{|l|r|}
\hline LFL & 0.7520 \\
\hline CFR Calatori & 0.3979 \\
\hline Amtrak & 0.2950 \\
\hline
\end{tabular}

\begin{tabular}{|l|l|}
\hline Amtrak & 0.2899 \\
\hline Gysev & 0.2560 \\
\hline
\end{tabular}

\begin{tabular}{|l|l|}
\hline Gysev & 0.2453 \\
\hline NS & 0.2240 \\
\hline SNCB/NMBS & 0.2063 \\
\hline ÖBB & 0.2041 \\
\hline
\end{tabular}

\begin{tabular}{|l|r|}
\hline ÖBB & 0.2041 \\
\hline CIE & 0.1997 \\
\hline
\end{tabular}

\begin{tabular}{|l|l|}
\hline SNCF & 0.1931 \\
\hline
\end{tabular}

\begin{tabular}{|l|r|}
\hline ATOC & 0.1878 \\
\hline FS & 0.1682 \\
\hline
\end{tabular}

\begin{tabular}{|l|l|l|l|}
\hline FS & 0.1682 & SBB/CFF/FFS & 0.0830 \\
\hline VIA & 0.1647 & DBAG * & 0.0825 \\
\hline BLS & 0.1552 & BRC & 0.0817 \\
\hline NIR & 0.1525 & PKP & 0.0813 \\
\hline Japan & 0.1502 & IR & 0.0760 \\
\hline SBB/CFF/FFS & 0.1456 & SNCB/NMBS & 0.0682 \\
\hline LG & 0.1396 & SNCF & 0.0626 \\
\hline VR & 0.1375 & LG & 0.0609 \\
\hline HZ & 0.1338 & Japan & 0.0573 \\
\hline SZ & 0.1329 & SZ & 0.0566 \\
\hline NSB & 0.1155 & ZSSK Cargo & 0.0558 \\
\hline $\boldsymbol{M A V ~ S t a r t}$ & 0.1084 & FEVE & 0.0458 \\
\hline RENFE & 0.1076 & VR & 0.0435 \\
\hline SJ & 0.1044 & LDZ & 0.0417 \\
\hline FGC & 0.1019 & CP Carga & 0.0362 \\
\hline $\boldsymbol{P K \boldsymbol { P }}$ & 0.0955 & RENFE & 0.0347 \\
\hline FEVE & 0.0831 & US Class I & 0.0257 \\
\hline Euskotren & 0.0818 & Canada Frt & 0.0236 \\
\hline $\boldsymbol{C D}$ & 0.0810 & CR & 0.0232 \\
\hline CP & 0.0720 & EVR & 0.0142 \\
\hline BDZ & 0.0604 & HZ & 0.0100 \\
\hline DSB & 0.0590 & & \\
\hline
\end{tabular}

\begin{tabular}{|l|l|}
\hline DSB & 0.0590 \\
\hline$Z S S K$ & 0.0483 \\
\hline CR $^{* *}$ & 0.0469 \\
\hline $\mathrm{IR}$ & 0.0201 \\
\hline
\end{tabular}

\begin{tabular}{|c|c|} 
Railway & $\begin{array}{c}\text { Average Freigh } \\
\text { Revenue/ Tonne } \\
\mathrm{Km}\end{array}$
\end{tabular}

\begin{tabular}{l|c} 
& $\mathrm{Km}$ \\
\hline Unifertrans & 0.1593 \\
\hline ÖBB & 0.1501 \\
\hline
\end{tabular}

\begin{tabular}{l|l} 
Gysev & 0.1501 \\
\hline
\end{tabular}

\begin{tabular}{|l|l|}
\hline BLS Cargo & 0.1357 \\
\hline
\end{tabular}

\begin{tabular}{|l|l|}
\hline CIE & 0.1087 \\
\hline
\end{tabular}

\begin{tabular}{l|l} 
CFR MARFA & 0.1077 \\
\hline
\end{tabular}

\begin{tabular}{|l|r|}
\hline FS & 0.1077 \\
\hline FGC & 0.1056 \\
\hline
\end{tabular}

\begin{tabular}{|l|r|}
\hline GFR & 0.1035 \\
\hline
\end{tabular}

\begin{tabular}{|l|l|}
\hline Servtrans & 0.1020 \\
\hline$B D Z$ & 0.0975 \\
\hline
\end{tabular}

\begin{tabular}{|l|r}
\hline$B D Z$ & 0.097 \\
\hline$C D$ & 0.0842 \\
\hline
\end{tabular}

\begin{tabular}{|l|l|}
\hline $\boldsymbol{C D}$ & 0.0842 \\
\hline SBB/CFF/FFS & 0.0830 \\
\hline DBAG * & 0.0825 \\
\hline
\end{tabular}


Table 10

Rail Market Shares for Passengers and Freight *

\begin{tabular}{|c|c|c|c|c|c|}
\hline Country & $\begin{array}{l}\text { Rail Passenger } \\
\text { Share (\% Pass- } \\
\text { Km) of Rail, Bus } \\
\text { and Auto Traffic }\end{array}$ & Country & $\begin{array}{c}\text { Rail Share (\% } \\
\text { Tonne-Km) of } \\
\text { Truck Barge and } \\
\text { Pipeline Traffic }\end{array}$ & Country & $\begin{array}{c}\text { Rail Share ( } \% \\
\text { Tonne-Km) of Rail } \\
\text { and Truck Traffic } \\
\text { Only }\end{array}$ \\
\hline Austria & & Austria & 34.9 & Austria & 41.6 \\
\hline Belgium & 7.4 & Belgium & 13.7 & Belgium & 16.8 \\
\hline Denmark & 9.2 & Denmark & 14.6 & Denmark & 17.9 \\
\hline Finland & 5.0 & Finland & 25.8 & Finland & 25.9 \\
\hline France & 9.3 & France & 14.4 & France & 16.1 \\
\hline $\begin{array}{l}\text { Germany } \\
\text { (DBAG) }\end{array}$ & 8.1 & $\begin{array}{l}\text { Germany } \\
\text { (DBAG) }\end{array}$ & 22.3 & $\begin{array}{l}\text { Germany } \\
\text { (DBAG) }\end{array}$ & 25.9 \\
\hline Greece & 3.8 & Greece & 1.7 & Greece & 1.7 \\
\hline Ireland & & Ireland & 1.0 & Ireland & 1.0 \\
\hline Italy & 5.6 & Italy & 7.8 & Italy & 8.3 \\
\hline Luxembourg & & Luxembourg & 2.9 & Luxembourg & 3.0 \\
\hline Netherlands & 10.7 & Netherlands & 6.8 & Netherlands & 15.1 \\
\hline Portugal & & Portugal & 15.0 & Portugal & 15.3 \\
\hline Spain & 5.5 & Spain & 3.6 & Spain & 3.7 \\
\hline Sweden & 8.8 & Sweden & 40.6 & Sweden & 40.6 \\
\hline UK & 7.4 & UK & 11.3 & UK & 12.0 \\
\hline EU 15 & 7.0 & EU 15 & 15.4 & EU 15 & 17.5 \\
\hline Bulgaria & 17.5 & Bulgaria & 12.5 & Bulgaria & 13.4 \\
\hline Czech Rep. & 8.2 & Czech & 19.9 & Czech & 20.7 \\
\hline Slovakia & 7.2 & Slovak & 21.0 & Slovak & 21.5 \\
\hline Estonia & 9.9 & Estonia & 48.8 & Estonia & 48.8 \\
\hline Hungary & 10.2 & Hungary & 17.9 & Hungary & 20.9 \\
\hline Latvia & 27.2 & Latvia & 59.5 & Latvia & 63.8 \\
\hline \begin{tabular}{|l|} 
Lithuania \\
\end{tabular} & 1.2 & Lithuania & 40.6 & Lithuania & 41.2 \\
\hline Poland & 5.2 & Poland & 18.1 & Poland & 19.7 \\
\hline Romania & 30.1 & Romania & 27.6 & Romania & 35.8 \\
\hline Slovenia & 2.7 & Slovenia & 63.3 & Slovenia & 63.3 \\
\hline EU 10 & 7.3 & EU 10 & 23.8 & EU 10 & 25.9 \\
\hline Croatia & 32.1 & Croatia & 18.0 & Croatia & 21.5 \\
\hline Norway & 4.6 & Norway & 15.0 & Norway & 17.2 \\
\hline Switzerland & 17.5 & Switzerland & 39.4 & Switzerland & 39.7 \\
\hline US & 0.2 & US & 32.3 & US & 39.0 \\
\hline Canada & 0.3 & Canada & 44.4 & Canada & 64.6 \\
\hline China & 36.4 & China & 26.8 & China & 36.4 \\
\hline Japan & 84.2 & Japan & 7.9 & Japan & 7.9 \\
\hline India & 14.1 & India & 33.2 & India & 35.6 \\
\hline
\end{tabular}

* Note: This is taken from OECD website data

Source: See Appendix A 
Table 1

Development of Railway Traffic Over Time

\begin{tabular}{|c|c|c|c|c|c|c|c|c|c|c|c|c|c|c|c|c|c|}
\hline \multicolumn{2}{|c|}{ Total Passenger-Km } & 1970 & 1975 & 1980 & 1985 & 1990 & 1995 & 2000 & 2005 & 2006 & 2007 & 2008 & 2009 & 2010 & 2011 & \begin{tabular}{|c|} 
CAGR \\
1980 to \\
$2011(\%)$
\end{tabular} & $\begin{array}{c}\text { CAGR } \\
1995 \text { to } \\
2011(\%)\end{array}$ \\
\hline France & SNCF & 40979 & 50696 & 54660 & 62070 & 63761 & 55311 & 69571 & 76559 & 79483 & 81487 & 86664 & 85697 & 84860 & 86094 & 2.2 & 4.1 \\
\hline Germany & DBAG* & 62362 & 66177 & 63637 & 65157 & 61024 & 70334 & 74015 & 72497 & 74738 & 74677 & 76929 & 75579 & 77221 & 77567 & 0.9 & 0.9 \\
\hline UK & $\begin{array}{l}\text { BR/ATOC/Frt } \\
\end{array}$ & 30409 & 30256 & 31704 & 30256 & 33191 & 30000 & 38200 & 43100 & 46100 & 48800 & 50800 & 51500 & 54600 & 57500 & 2.9 & 6.1 \\
\hline EU 15 & & 219183 & 244950 & 250263 & 258071 & 269593 & 273724 & 298945 & 299741 & 313374 & 315847 & 334435 & 344443 & 344800 & 349668 & 1.6 & 2.3 \\
\hline & & & & & & & & & & & & & & & & & \\
\hline Czech Rep & $C D$ & & & & & & 8023 & 7266 & 6631 & 6887 & 6855 & 6759 & 6462 & 6553 & 6635 & na & -1.7 \\
\hline Poland & PKP & 36891 & 42819 & 46324 & 51978 & 50373 & 20960 & 19706 & 16742 & 16971 & 17081 & 17958 & 16454 & 15715 & 15740 & -5.0 & -2.6 \\
\hline EU 10 & & 101034 & 109558 & 119213 & 133724 & 131326 & 68520 & 54290 & 47105 & 47674 & 46339 & 46165 & 40264 & 38871 & 38920 & -5.2 & -5.0 \\
\hline & & & & & & & & & & & & & & & & & \\
\hline Us & Amtrak & & 6031 & 7637 & 8042 & 9769 & 8924 & 8970 & 8660 & 8706 & 9309 & 9943 & 9476 & 9518 & 10331 & 1.4 & 1.3 \\
\hline Japan & Japan & 189726 & 215289 & 193143 & 197463 & 237551 & 248993 & 240657 & 245957 & 249029 & 255201 & 253555 & 244235 & 244591 & 245612 & 1.2 & -0.1 \\
\hline Switzerland & SBB/CFF/FFS & 8168 & 7984 & 9167 & 9381 & 11049 & 11712 & 12835 & 13830 & 14267 & 15132 & 16142 & 16182 & 16868 & 17156 & 3.0 & 3.5 \\
\hline
\end{tabular}

\begin{tabular}{|c|c|c|c|c|c|c|c|c|c|c|c|c|c|c|c|c|c|}
\hline Freight Tonn & e-Km $(000,000)$ & 1970 & 1975 & 1980 & 1985 & 1990 & 1995 & 2000 & 2005 & 2006 & 2007 & 2008 & 2009 & 2010 & 2011 & $\begin{array}{c}\text { CAGR } \\
1980 \text { to } \\
2011(\%) \\
\end{array}$ & \begin{tabular}{|c|} 
CAGR \\
1995 to \\
$2011(\%)$ \\
\end{tabular} \\
\hline France & SNCF & 67586 & 63473 & 68815 & 55121 & 50667 & 48136 & 55352 & 40701 & 40924 & 40634 & 35932 & 26482 & 22840 & 23241 & -5.0 & -6.4 \\
\hline Germany & DBAG * & 109963 & 103114 & 118988 & 120493 & 101166 & 69442 & 76815 & 81722 & 88407 & 92077 & 91178 & 72257 & 80378 & 111980 & -0.3 & 4.4 \\
\hline UK & BR/ATOC/Frt & 24550 & 20960 & 17640 & 16047 & 15986 & 12537 & 18090 & 21700 & 21880 & 21180 & 20630 & 19060 & 19230 & 20000 & 0.6 & 4.3 \\
\hline EU 15 & & 387140 & 361684 & 404831 & 393535 & 354582 & 219743 & 249703 & 237664 & 253120 & 251712 & 246595 & 178880 & 183365 & 240223 & -2.5 & 0.8 \\
\hline Czech Rep & $C D$ & & & & & & 22634 & & & & & & & & & na] & 5.5 \\
\hline Poland & PKP & 98233 & 127505 & 132576 & 118863 & 81776 & 68206 & 54015 & 45438 & 42651 & 43548 & 39200 & 29941 & 34327 & 37189 & -5.9 & $\begin{array}{l}-5.5 .4 \\
-5.4 \\
\end{array}$ \\
\hline EU 10 & & 267495 & 330140 & 350849 & 340652 & 253261 & 168657 & 144489 & 140046 & 138913 & 140534 & 131839 & 96287 & 98572 & 122353 & -4.9 & -2.9 \\
\hline US & Class 1 & 11173 & $1101 \mathrm{~g}$ & 134259 & 12812 & 15106 & 1907 & & 2478 & 588 & 58 & & 225 & & & 3.1 & \\
\hline Japan & Japan & 61482 & 46030 & 36961 & 21383 & 26803 & 24747 & 21800 & 22632 & 23014 & 23166 & 22100 & 20432 & 20255 & 20256 & -2.8 & -1.8 \\
\hline Switzerland & SBB/CFF/FFS & 6592 & 5139 & 7385 & 7049 & 8303 & 8156 & 10658 & 8571 & 8439 & 13368 & 12531 & 4181 & 7778 & 7656 & 0.2 & -0.6 \\
\hline
\end{tabular}

Table 12

Evolution of Operating Ratio and TU/Employee Over Time

\begin{tabular}{|l|l|r|r|r|r|r|r|r|r|r|r|r|r|r|r|r|}
\hline \multicolumn{2}{|c|}{ Operating Ratio \% } & $\mathbf{1 9 7 0}$ & $\mathbf{1 9 7 5}$ & $\mathbf{1 9 8 0}$ & $\mathbf{1 9 8 5}$ & $\mathbf{1 9 9 0}$ & $\mathbf{1 9 9 5}$ & $\mathbf{2 0 0 0}$ & $\mathbf{2 0 0 5}$ & $\mathbf{2 0 0 6}$ & $\mathbf{2 0 0 7}$ & $\mathbf{2 0 0 8}$ & $\mathbf{2 0 0 9}$ & $\mathbf{2 0 1 0}$ & $\mathbf{2 0 1 1}$ \\
\hline France & SNCF & 100 & 105 & 104 & 113 & $\mathbf{1 0 7}$ & 107 & $\mathbf{9 8}$ & 96 & 96 & 96 & 96 & 100 & 93 & 89 \\
\hline & RFF & - & - & - & - & - & - & - & 95 & 95 & 101 & 104 & 78 & 77 & 79 \\
\hline Germany & DBAG * & 109 & 122 & 114 & 111 & 117 & 99 & 98 & 95 & 93 & 92 & 93 & 94 & 95 & 95 \\
\hline UK & BR & 88 & 97 & 103 & 100 & 102 & 92 & - & - & - & - & - & - & - & - \\
\hline Czech Rep & CD & - & - & - & - & - & 110 & 109 & 102 & 101 & 100 & 111 & 101 & 102 & 97 \\
\hline Poland & PKP & 113 & 131 & 103 & 91 & 91 & 102 & 116 & 112 & 105 & 101 & 110 & 111 & 106 & 100 \\
\hline United States & Class I & 96 & 97 & 93 & 91 & 87 & 86 & 85 & 82 & 79 & 78 & 77 & 78 & 73 & 73 \\
\hline & Amtrak & - & 210 & 238 & 198 & 154 & 180 & - & 156 & 147 & 146 & 142 & - & 153 & 150 \\
\hline Japan & Japan & 114 & 151 & 134 & 157 & 91 & 80 & 85 & 82 & 61 & 81 & 82 & 86 & 85 & 83 \\
\hline & SBB/CFF/FFS & 100 & 127 & 122 & 107 & 100 & 99 & 95 & 101 & 95 & 97 & 94 & 93 & 94 & 93 \\
\hline
\end{tabular}

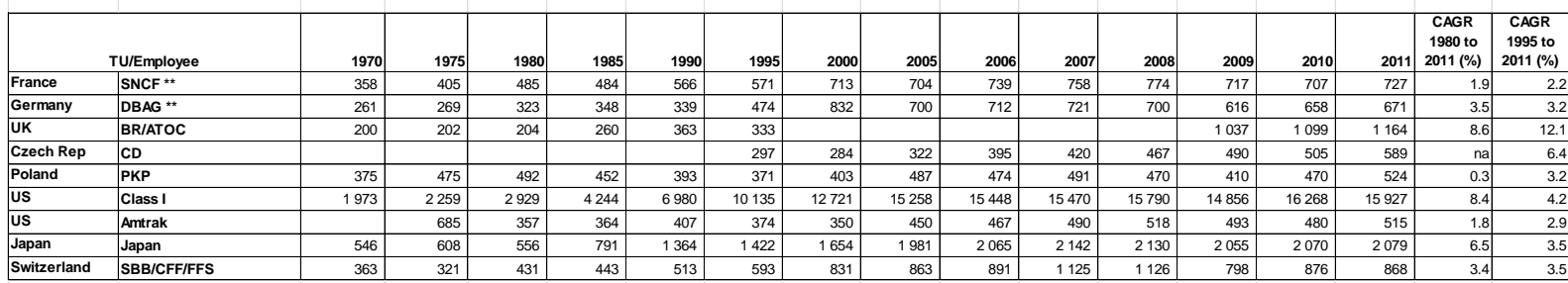

* Prior to $1995, \mathrm{DB}$ AG is the older DB

** Both SNCF and DB AG are affected by the presence of a large number of non-rail employees, which cannot be corrected for 1980 and 1995 . If later years include a higher percentage of non-rail

than earlier years, then TU/Employee will look too low, and productivity growth will also look too low. 
Average Passenger Revenue/Passenger-Km Expressed in 2011 PPP International Dollars

\begin{tabular}{|l|l|l|l|l|l|l|l|l|l|l|l|l|l|l|l|l|}
\hline & & 1970 & 1975 & 1980 & 1985 & 1990 & 1995 & 2000 & 2005 & 2006 & 2007 & 2008 & 2009 & 2010 & 2011 \\
\hline France & SNCF & 0.0478 & 0.0611 & 0.0877 & 0.1257 & 0.1249 & 0.1090 & 0.1234 & 0.1767 & 0.1761 & 0.1764 & 0.1793 & 0.1905 & 0.1908 & 0.1931 \\
\hline Germany & DBAG ${ }^{* *}$ & 0.1079 & 0.1673 & 0.2015 & 0.1993 & 0.1906 & 0.1808 & 0.1852 & 0.2167 & 0.2080 & 0.2043 & 0.2045 & 0.2193 & 0.2266 & 0.2560 \\
\hline UK & BR/ATOC & 0.0332 & 0.0483 & 0.0947 & 0.1238 & 0.1479 & 0.1661 & 0.1609 & 0.1591 & 0.1615 & 0.1635 & 0.1715 & 0.1842 & 0.1832 & 0.1878 \\
\hline Czech Rep & CD & & & & & & 0.0419 & 0.0749 & 0.0768 & 0.0750 & 0.0754 & 0.0722 & 0.0827 & 0.0808 & 0.0810 \\
\hline Poland & PKP & & & & & 0.0041 & 0.0558 & 0.0687 & 0.1004 & 0.1032 & 0.0855 & 0.0882 & 0.1051 & 0.0997 & 0.0955 \\
\hline US & Amtrak & & 0.1174 & 0.1389 & 0.1451 & 0.1602 & 0.1510 & 0.1705 & 0.2171 & 0.2340 & 0.2505 & 0.2935 & 0.2791 & 0.2790 & 0.2899 \\
\hline Japan & All & 0.1265 & - & 0.2164 & - & - & 0.1739 & 0.1682 & 0.1580 & 0.1553 & 0.1518 & 0.1522 & 0.1573 & 0.1502 & 0.1502 \\
\hline Switzerland & SBB/CFF/FFS & 0.1107 & 0.1355 & 0.1428 & 0.2244 & 0.1304 & 0.1356 & 0.1158 & 0.1569 & 0.1247 & 0.2016 & 0.1969 & 0.1589 & 0.1449 & 0.1456 \\
\hline
\end{tabular}

Average Freight Revenue/Tonne-Km Expressed in 2011 PPP International Dollars

\begin{tabular}{|c|c|c|c|c|c|c|c|c|c|c|c|c|c|c|c|c|}
\hline & & 1970 & 1975 & 1980 & 1985 & 1990 & 1995 & 2000 & 2005 & 2006 & 2007 & 2008 & 2009 & 2010 & 2011 & 2012 \\
\hline France & SNCF & 0.0458 & 0.0584 & 0.0758 & 0.1116 & 0.0942 & 0.0792 & 0.0528 & 0.0569 & 0.0546 & 0.0544 & 0.0584 & 0.0646 & 0.0642 & 0.0626 & \\
\hline Germany & DBAG $^{* *}$ & 0.1372 & 0.1755 & 0.1610 & 0.1513 & 0.1161 & 0.0900 & 0.0601 & & 0.0471 & 0.0475 & 0.0536 & 0.0535 & 0.0544 & 0.0564 & 0.0587 \\
\hline UK & BR/Frt & 0.0356 & 0.0538 & 0.1075 & 0.1094 & 0.1161 & na & na & na & na & na & na & na & na & na & \\
\hline Czech Rep & $C D(2003)$ & & & & & & 0.0988 & 0.1336 & 0.1062 & 0.0910 & 0.0845 & 0.0819 & 0.0751 & 0.0946 & 0.0842 & \\
\hline Poland & $P K P$ & & & & & 0.0232 & 0.0724 & 0.0825 & 0.0835 & 0.0839 & 0.0803 & 0.0846 & 0.0854 & 0.0810 & 0.0813 & \\
\hline United States & Class I & 0.0342 & 0.0416 & 0.0458 & 0.0413 & 0.0306 & 0.0243 & 0.0185 & 0.0190 & 0.0200 & 0.0207 & 0.0232 & 0.0213 & 0.0232 & 0.0257 & 0.0263 \\
\hline Japan & All & 0.1193 & 0.1229 & 0.1718 & - & - & 0.0800 & 0.0674 & 0.0575 & 0.0565 & 0.0557 & 0.0564 & 0.0600 & 0.0573 & . & \\
\hline Switzerland & SBB/CFF/FFS & 0.2121 & 0.2823 & 0.2235 & 0.2111 & 0.1574 & 0.1279 & 0.0925 & 0.0954 & 0.0949 & 0.0753 & 0.0780 & - & 0.0883 & 0.0830 & \\
\hline
\end{tabular}

** Before 1995, this uses the old DB data (DR not included). Freight rates are recalculated from DB Annual Reports to remove apparent Schenker distortion.

Table 14

Evolution of Railway Market Shares

Rail Market Share (\% Passenger-Km) of Rail, Auto and Bus Passenger Traffic

\begin{tabular}{|c|c|c|c|c|c|c|c|c|c|c|c|c|c|c|}
\hline & 1970 & \begin{tabular}{|l|}
1975 \\
\end{tabular} & 1980 & 1985 & \begin{tabular}{|l|}
1990 \\
\end{tabular} & 1995 & 2000 & 2005 & 2006 & 2007 & 2008 & 2009 & 2010 & 2011 \\
\hline France & 11.0 & 11.2 & 10.0 & 10.5 & 8.8 & 7.0 & 8.1 & 8.3 & 8.6 & 8.7 & 9.3 & 9.2 & 9.1 & 9.3 \\
\hline Germany & 8.8 & 7.7 & 7.1 & 7.4 & 6.3 & 7.4 & 7.7 & 7.6 & 7.7 & 7.7 & 8.0 & 7.9 & 8.0 & 8.1 \\
\hline UK & 8.1 & 7.5 & 6.7 & 6.0 & 5.1 & 4.3 & 5.4 & 5.7 & 5.9 & 6.3 & 6.6 & 6.7 & 7.1 & 7.4 \\
\hline EU 15 & 10.4 & 9.5 & 8.5 & 8.1 & 7.0 & 6.6 & 6.9 & 7.0 & 7.2 & 7.3 & 7.6 & 7.9 & 7.8 & 7.0 \\
\hline & & & & & & & & & & & & & & \\
\hline Czech Republic & & & & & & 10.9 & 9.1 & 7.9 & 8.0 & 7.8 & 7.7 & 7.4 & 8.1 & 8.2 \\
\hline \begin{tabular}{|l|} 
Poland \\
\end{tabular} & 55.9 & 48.3 & 48.5 & 36.1 & 30.6 & 12.7 & 9.8 & 7.3 & 6.9 & 6.8 & 6.3 & 5.7 & 5.3 & 5.2 \\
\hline EU 10 & 50.1 & 40.1 & 35.8 & 32.6 & 29.1 & 16.2 & 12.3 & 9.0 & 8.6 & 8.3 & 7.8 & 7.3 & 7.0 & 7.3 \\
\hline US & 0.4 & 0.1 & 0.1 & 0.1 & 0.3 & 0.2 & 0.2 & 0.2 & 0.2 & 0.2 & 0.2 & 0.2 & 0.2 & 0.2 \\
\hline \begin{tabular}{|l|} 
Japan \\
\end{tabular} & 50.4 & 47.3 & 42.2 & 40.3 & 31.2 & 30.4 & 28.8 & 29.5 & 30.1 & 30.6 & 30.9 & 30.4 & & \\
\hline Switzerland & 16.9 & 14.2 & 12.9 & 12.3 & 14.8 & 14.4 & 13.6 & 16.1 & 16.4 & \begin{tabular}{ll|}
16.9 \\
\end{tabular} & 17.0 & 17.3 & 17.5 & 17.5 \\
\hline
\end{tabular}

Rail Market Share (\% Net Tonne-Km) of Rail Plus Truck Traffic

\begin{tabular}{|c|c|c|c|c|c|c|c|c|c|c|c|c|c|c|}
\hline & 1970 & 1975 & 1980 & 1985 & 1990 & 1995 & 2000 & 2005 & 2006 & 2007 & 2008 & 2009 & 2010 & 2011 \\
\hline France & 50.5 & 42.1 & 39.8 & 39.1 & 30.2 & 22.9 & 23.1 & 17.0 & 17.2 & 17.1 & 17.1 & 16.2 & 14.7 & 16.1 \\
\hline Germany & 47.5 & 36.1 & 33.9 & 32.3 & 37.8 & 22.9 & 21.6 & 23.5 & 24.5 & 25.0 & 25.3 & 23.8 & 25.5 & 25.9 \\
\hline UK & 22.4 & 18.6 & 16.2 & 13.7 & 10.7 & 8.3 & 10.5 & 11.4 & 11.6 & 10.9 & 11.5 & 12.0 & 10.8 & 12.0 \\
\hline EU 15 & 32.2 & 23.6 & 21.5 & 20.5 & 20.3 & 15.4 & 15.6 & 14.3 & 15.2 & 15.2 & 15.4 & 14.3 & 14.8 & 15.4 \\
\hline & & & & & & & & & & & & & & \\
\hline Czech & & & & & & & & & & & & & & \\
\hline Republic & & & & & & 44.9 & 30.9 & 25.5 & 23.9 & 25.3 & 23.3 & 22.2 & 21.0 & 20.7 \\
\hline Poland & 86.3 & 79.9 & 75.2 & 76.7 & 67.5 & 57.1 & 41.9 & 29.4 & 28.2 & 25.4 & 23.0 & 18.5 & 18.5 & 19.7 \\
\hline EU 10 & 78.4 & 74.4 & 69.3 & 69.4 & 63.8 & 48.0 & 40.0 & 29.0 & 27.5 & 26.0 & 24.8 & 22.1 & 22.4 & 23.8 \\
\hline & & & & & & & & & & & & & & \\
\hline United States* & 65.1 & 62.5 & 62.7 & 59.5 & 59.7 & 59.9 & 56.4 & 57.5 & 59.0 & 58.0 & 54.8 & 54.5 & & \\
\hline Japan & 31.7 & 26.6 & 17.3 & 9.6 & 9.0 & 7.9 & 6.6 & 6.4 & 6.3 & 6.2 & 6.0 & 5.8 & 7.7 & 7.9 \\
\hline Switzerland & 59.0 & 52.7 & 53.2 & 47.8 & 44.0 & 42.2 & 44.9 & 42.6 & 43.3 & 41.3 & 41.5 & 38.4 & 39.4 & 39.7 \\
\hline
\end{tabular}

* US calculated on different basis using AAR statistics for rail versus intercity truck only. OECD does not provide similar data for other countries. 
Table 15

Rail Liberalization Index for EU Railways

\begin{tabular}{|c|c|c|c|c|c|c|c|c|c|c|c|c|c|c|c|c|c|c|c|c|}
\hline & \multicolumn{2}{|c|}{$>800$} & \multicolumn{3}{|c|}{ Advanced } & & & & & & & & & & & & & & & \\
\hline & \multicolumn{2}{|c|}{600 to 800} & \multicolumn{3}{|c|}{ On Schedule } & & & & & & & & & & & & & & & \\
\hline & \multicolumn{2}{|c|}{300 to 600} & \multicolumn{3}{|c|}{ Delayed } & & & & & & & & & & & & & & & \\
\hline & \multicolumn{2}{|c|}{$<300$} & \multirow{2}{*}{\multicolumn{3}{|c|}{$\begin{array}{c}\text { Pending Departure } \\
\text { No data }\end{array}$}} & & & & & & & & & & & & & & & \\
\hline & & & & & & & & & \multicolumn{12}{|c|}{ LEX, ACCESS and COM Details } \\
\hline & \multicolumn{4}{|c|}{ Overall Liberalization } & \multicolumn{2}{|c|}{2007} & \multicolumn{2}{|c|}{2011} & \multicolumn{4}{|c|}{ LEX } & \multicolumn{4}{|c|}{ ACCESS } & \multicolumn{4}{|c|}{ COM } \\
\hline Country & 2002 & 2004 & 2007 & 2011 & Frt. & Pass. & Frt. & \begin{tabular}{|l|} 
Pass. \\
\end{tabular} & 2002 & 2004 & 2007 & 2011 & 2002 & 2004 & 2007 & 2011 & 2002 & 2004 & 2007 & 2011 \\
\hline UK & 805 & 781 & 827 & 865 & 848 & 798 & 862 & 852 & 960 & 940 & 969 & 980 & 740 & 715 & 791 & 837 & 780 & 580 & 793 & 866 \\
\hline DE & 760 & 728 & 826 & 842 & 844 & 809 & 875 & 814 & 840 & 750 & 905 & 935 & 840 & 720 & 807 & 819 & 520 & 505 & 555 & 615 \\
\hline SE & 760 & 729 & 825 & 872 & 908 & 742 & 896 & 855 & 800 & 680 & 857 & 960 & 760 & 760 & 817 & 850 & 720 & 510 & 633 & 577 \\
\hline NL & 720 & 695 & 809 & 817 & 887 & 732 & 884 & 779 & 760 & 670 & 865 & 887 & 820 & 710 & 795 & 799 & 460 & 455 & 509 & 680 \\
\hline AT & 430 & 579 & 788 & 806 & 852 & 727 & 873 & 761 & 680 & 530 & 819 & 895 & 410 & 600 & 781 & 784 & 240 & 232 & 349 & 575 \\
\hline DK & 720 & 693 & 788 & 825 & 811 & 757 & 851 & 808 & 860 & 790 & 821 & 925 & 770 & 650 & 780 & 800 & 480 & 390 & 8 & 655 \\
\hline $\mathrm{CH}$ & 650 & 677 & 757 & 741 & 848 & 662 & 850 & 680 & 600 & 605 & 670 & 678 & 770 & 710 & 778 & 756 & 440 & 95 & 9 & 509 \\
\hline $\mathrm{PL}$ & & 549 & 739 & 737 & 786 & 692 & 826 & 699 & & 600 & 783 & 803 & & 530 & 728 & 720 & & 75 & 0 & 518 \\
\hline$\overline{C Z}$ & & 549 & 738 & 738 & 798 & 679 & 783 & 705 & & 530 & 839 & 786 & & 560 & 713 & 726 & & 215 & 279 & 422 \\
\hline RO & & & 722 & 726 & 797 & 650 & 834 & 650 & & & 822 & 783 & & & 697 & 711 & & & 40 & 487 \\
\hline PT & 380 & 668 & 707 & 737 & 797 & 619 & 847 & 676 & 700 & 820 & 829 & 884 & 290 & 605 & 676 & 701 & 220 & 190 & 0 & 434 \\
\hline SK & & 458 & 700 & 738 & 756 & 643 & 793 & 702 & & 535 & 853 & 857 & & 430 & 662 & 708 & & 60 & 31 & 381 \\
\hline NO & 390 & 589 & 698 & 729 & 836 & 574 & 861 & 652 & 580 & 570 & 777 & 769 & 410 & 595 & 679 & 719 & 140 & 135 & 274 & 482 \\
\hline $\mathrm{EE}$ & & 257 & 691 & 729 & 727 & 667 & 781 & 701 & & 380 & 728 & 840 & & 205 & 680 & 702 & & 245 & 704 & 629 \\
\hline LT & & 222 & 684 & 592 & 744 & 624 & 703 & 530 & & 260 & 820 & 730 & & 210 & 650 & 558 & & 165 & 184 & 120 \\
\hline IT & 560 & 688 & 676 & 737 & 734 & 617 & 809 & 706 & 660 & 740 & 819 & 795 & 680 & 670 & 640 & 722 & 240 & 225 & 293 & 470 \\
\hline SI & & 326 & 665 & 672 & 743 & 585 & 799 & 590 & & 550 & 622 & 655 & & 230 & 675 & 676 & & 120 & 153 & 337 \\
\hline BG & & & 652 & 718 & 761 & 557 & 806 & 668 & & & 722 & 839 & & & 635 & 688 & & & 241 & 421 \\
\hline LV & & 516 & 650 & 587 & 733 & 576 & 747 & 500 & & 580 & 683 & 780 & & 485 & 642 & 539 & & 225 & 313 & 411 \\
\hline $\mathrm{BE}$ & 395 & 461 & 649 & 753 & 780 & 518 & 881 & 663 & 380 & 425 & 740 & 820 & 500 & 475 & 626 & 737 & 180 & 180 & 201 & 424 \\
\hline HU & & 366 & 637 & 658 & 740 & 533 & 780 & 592 & & 485 & 731 & 822 & & 320 & 613 & 616 & & 125 & 275 & 522 \\
\hline FI & 410 & 542 & 636 & 672 & 732 & 540 & 753 & 661 & 620 & 640 & 732 & 729 & 440 & 505 & 612 & 657 & 160 & 140 & 145 & 156 \\
\hline ES & 195 & 148 & 630 & 583 & 785 & 486 & 770 & 485 & 300 & 250 & 711 & 701 & 180 & 105 & 610 & 554 & 140 & 110 & 151 & 333 \\
\hline LU & 280 & 467 & 581 & 585 & 688 & 474 & 742 & 508 & 520 & 530 & 551 & 669 & 220 & 440 & 588 & 564 & 152 & 120 & 115 & 104 \\
\hline FR & 340 & 305 & 574 & 612 & 727 & 431 & 772 & 521 & 340 & 360 & 595 & 650 & 430 & 280 & 568 & 602 & 152 & 130 & 178 & 334 \\
\hline GR & 210 & 162 & 559 & 592 & 690 & 429 & 698 & 559 & 260 & 305 & 619 & 859 & 240 & 100 & 544 & 525 & 100 & 100 & 133 & 136 \\
\hline IE & 295 & 149 & 333 & 467 & 458 & 206 & 603 & 399 & 520 & 180 & 332 & 414 & 280 & 130 & 338 & 481 & 100 & 100 & 115 & 120 \\
\hline Sample & 17 & 25 & 27 & 27 & 27 & 27 & 27 & 27 & 17 & 25 & 27 & 27 & 17 & 25 & 27 & 27 & 17 & 25 & 27 & 27 \\
\hline EU 15 & 484 & 520 & 681 & 718 & 769 & 592 & 808 & 670 & 613 & 574 & 744 & 807 & 507 & 498 & 665 & 695 & 310 & \begin{tabular}{|l|}
264 \\
\end{tabular} & 325 & 432 \\
\hline EU 10 & - & 405 & 688 & 690 & 759 & 621 & 785 & 634 & - & 490 & 760 & 790 & - & 371 & 670 & 664 & - & 191 & 346 & 425 \\
\hline EU 25 & & 480 & 683 & 706 & 765 & 604 & 799 & 655 & & 545 & 751 & 800 & & 454 & 667 & 683 & & 239 & 333 & 429 \\
\hline & & & & & & & & & & & & & & & & & & & & \\
\hline $1 \mathrm{pg}$ & & & & 12 & & & 66 & 67 & & & & 52 & & & & 59 & & & & 63 \\
\hline $7 \mathrm{p}$ & & 32 & 57 & & 71 & 78 & & & & & 59 & & & & 64 & & & & 68 & \\
\hline $24 p$ & & & & & & & & & & 27 & & & & 29 & & & & & & \\
\hline $002 \mathrm{pg}$ & 5 & & & & & & & & 7 & & & & 9 & & & & 11 & & & \\
\hline
\end{tabular}

Note: 2002 Indices were visually estimated from graphs. Numbers shown were then calculated by multiplying the original numbers by 4,2 and 4 respectively.

Source: Rail Liberalization Index report of indicated year 


\section{Appendix A}

\section{A Note on the Sources of Data for This Paper}

The good news with railway data -- as opposed to trucking, air and water transport data -- is that railways probably report more information in more detail than other modes. Depending on the country and the railway (and the year) it is possible to collect all the data used in this paper along with even more detailed data on types of service, commodities, etc. The bad news is that data taken from different sources purporting to represent the same thing (passenger-km in a particular year) are not always (or even often) consistent. In addition, not all railways report all data in any given year and some railways do not bother to report at all. In some cases, restructuring has meant that most information is lost on those parts of the railway that are established separately (Green Cargo and UK freight operators). The net result is that most of the apparently precise information in rail data sets has to be taken with a grain of salt and that there is a real need for action by governments and the EU to take action to improve the quality and amount of rail data reported to the public. Thompson 2007 discusses this issue in more detail, and it should be an issue for this conference.

The basic source of EU railway information is the International Union of Railways (UIC). This includes "Railway Time-Series Data 1970-2000," "Railway Time-Series Data 2008" (the electronic form was used) and various issues of the "International Railway Statistics" for 2002 through 2011. Some of these data were manually transcribed, which may have introduced errors attributable only to the authors and not the UIC.

The source of U.S. data for Class I freight railways is "Analysis of Class I Railroads" as published by the Surface Transportation Board (STB). This report has existed essentially in its current form in an unbroken series since the beginning of the $20^{\text {th }}$ century. We have also used the "Public Use Carload Waybill Sample" with added calculations of variable costs at the two-digit Standard Transportation Commodity Code (STCC) level as furnished by the STB and processed by the Association of American Railroads (AAR). In some cases we have used data from "Railroad Facts," a statistical compendium of Class I freight railroad activity published by the AAR. Amtrak data were taken from various Amtrak statistical reports, notably the "Monthly Performance Report" for September of various years that contain annual fiscal year data along with various Amtrak Annual Reports.

Canadian data were taken from various issues of "Railway Trends" published by the Railway Association of Canada (RAC) and data taken from Statistics Canada as processed by the RAC.

UK data are taken from UIC reports and from various editions of "National Rail Trends Yearbook" published by the Office of the Rail Regulator.

Chinese data are taken from "China Railways Facts 2008 edition" published by the Statistics Center of the Ministry of Railways along with updated figures provided to us by the Ministry. 
Data on Tonne-Kms and Passenger-Kms used for calculation of market shares were taken from the OECD website.

Data on inflation indices, currency values and PPP conversion factors are taken from the World Bank's "World Development Indicators" that generally cover all countries over the period 1960 to present.

For reasons of space and brevity, we have not included the full set of 33 Excel spreadsheets covering 81 railway entities (26 existing or former countries) over 41 years. These are available on request from the authors (lou.thompson@gmail.com). The Tables presented are extracted from these supporting spreadsheets. 


\section{Bibliography}

Beck, Arne, Heiner Bente and Martin Schilling, 2013, "Railway Efficiency," OECD

Crew, M. A., \& Kleindorfer, P. R. (Eds.). (2004). Competitive transformation of the postal and delivery sector (Vol. 46). Springer.

ECMT, (2007), “Competitive Tendering of Rail Services,” ECMT. Paris.

Gassner, K.; Popov, A.; Pushak, N. (2009). Does Private Sector Participation Improve Performance in Electricity and Water Distribution? Trends and Policy Options; no. 6. The World Bank.

International Transport Forum (2014), "Peer Review of Freight Railway Development in Mexico," February 2014.

Kirchner, Christian (2011), "Rail Liberalization Index 2011," IBM Global Business Services. Earlier issues are 2002, 2004 and 2007.

McCullough, Gerard J. and Louis S. Thompson (2012), "A Further Look at the Staggers Act: Mining the Available Data", Elsevier, research in Transportation Business and Management, 10.1016/j.rtbm.2012.11.009.

Nash CA, Smith A.S.J., van de Velde, D., Mizutani, F., Uranishi, S. (2013) Structural reforms in the railways: Incentive misalignment and cost implications. Research in Transportation Economics, 48, 16-23.

Nash, C., Nilsson, J.E., \& Link, H. (2013). Comparing three models for introduction of competition into railways. Journal of Transport Economics and Policy (JTEP), 47(2), 191-206.

Parker, D. (2004). The UK's Privatisation Experiment: The Passage of Time Permits a Sober Assessment. CESIFO working paper no. 1126, category 9: industrial organization.

Thompson, Louis S. (2007), "Railway Accounts for Effective Regulation,” ECMT

Thompson, Louis S. (2013), "Recent Developments in Rail Transportation Services," OECD

Van de Velde, D., C. Nash, Smith, A.; Mizutani, F., Uranishi, S.; Lijesen, M.; Zschoche, F. (2012), EVES-Rail - Economic effects of Vertical Separation in the railway sector Amsterdam/Brussels. Publisher: inno-V (Amsterdam) in cooperation with University of Leeds - ITS, Kobe University, VU Amsterdam University and Civity Management Consultants.

Vasallo, Jose Manuel and Mark Fagan (2005), "Nature or Nurture: Why do Railroads Carry Greater Freight Share in the United States than in Europe," Harvard University Research Working Paper Series WP05-15. 
